\title{
Doña María Pacheco, de Ignacio García Malo, y su compleja interpretación política
}

Felipe Rodríguez Morín Instituto Feijoo de Estudios del Siglo XVIII

CES.XVIII, núm. 21 (2011), págs. 233-285. 
Resumen: Tildada Doña María Pacheco de absolutista por gran parte de la crítica, sobre todo a raíz de los comentarios vertidos en 1970 por René Andioc, en Sur la querelle du téâtre au temps de Leandro Fernández de Moratín, pretende este trabajo atemperar de modo sustancial aquellos juicios que la tachaban de reaccionaria.

A la luz de esta nueva interpretación que proponemos, la tríada principal de argumentos en la que, con apoyo en alguno o en varios de ellos, solía fundamentarse su presunta exaltación del absolutismo - -a) ciertos pasajes introductorios de la obra impresa, b) palabras finales de la protagonista y c) fría acogida del público por entender que se denostaba a los comuneros- parecen ahora pilares que no sólo se descubren agrietados en aquel sentido de proclamar sin ambages las razones incontestables del monarca para aplastar las disidencias, sino que apuntalan, por contra, la idea de que han de ser la moderación y buen gobierno de los de arriba, así como la sensatez y prudencia de los de abajo, los factores esenciales en los cuales una nación debe asentar su convivencia pacífica.

Palabras clave: Ignacio García Malo. María Pacheco. Estabilidad social. Prudencia, justicia, despotismo. 
Dn. Ygnacio Garcia Malo, clerigo de Menores.- Pide licencia para imprimir dos tragedias que ha compuesto intituladas una Guillermo de Hanan ${ }^{1}$ y otra $D^{a}$ Maria Pacheco: y también para una Comedia heroica que igualmente ha compuesto con el titulo de Enrico Duque de Cumberland².

Con fecha 6 de julio de 1786, aparece una nota ordenando la remisión de las citadas obras a la censura de don Ignacio López de Ayala, catedrático de Poesía de los Reales Estudios de San Isidro.

El dorso de ese folio lo configura una instancia de Manuel González Monroy, procurador de don Ignacio, firmada por ambos, en la que se menciona idéntico asunto: «Que mi parte tiene escrito una Comedia Heroica cuio titulo es Enrico Duque de Cumberland, y dos tragedias la una intitulada Guillermo Conde de Hanau y la otra $D^{a}$ Maria Pacheco, las que desea dar a Luz al publico» (figurando aquí, como se observa, correctamente escrito «Hanau»).

El 20 de agosto de ese 1786 informa Ayala al respecto: «De ôrden de V.A. hè leydo la tragedia intitulada Guillermo de Hanau y la comedia heroica ìntitulada Enrico Duque de Cumberland ${ }^{3}$, y hallandolas suficientemente arregladas, no encuentro reparo en qe V.A. conceda à su autor la licencia que pide para imprimirlas».

Sin embargo, como se ve, en el citado expediente de AHN no consta ningún pronunciamiento acerca del plácet para publicar Doña María Pacheco. Desconocemos el porqué.

Lo cierto es que en 1787 vuelve a someter la obra a censura y que, en el escrito petitorio, el procurador Manuel González Monroy resalta que su representado «a costa de continuadas fatigas, y desbelos à sacado la tragedia intitulada $\mathrm{D}^{\mathrm{a}}$ Maria Pacheco» ${ }^{4}$.

\footnotetext{
$1 \quad$ El error de la secretaría de la Sala de Gobierno del Consejo de Castilla, en cuanto a la última letra del título, transcrita como $n$ en vez de con la forma correcta, $u$, hará equivocar a más de un autor.

2 Archivo Histórico Nacional (en adelante AHN), Consejos, legajo 50.674.

3 Nada más sabemos de esta obra, ni siquiera si fue publicada. Guillermo Carnero («Doña María Pacheco (1788) de Ignacio García Malo y las normas de la tragedia neoclásica», Dieciocho, 17, 2 [invierno 1994], págs. 107-127, pág. 107) se refiere a ella como «una comedia perdida».

4 AHN, Consejos, legajo 5.553-75.
} 
Gana el 15 de octubre de ese año la conformidad de Iriarte, encargado de calificarla ${ }^{5}$, obteniendo finalmente el día 26 la definitiva aprobación de la Sala. Y en el año siguiente, de 1788, es puesta de molde en la imprenta de la Viuda de Miguel Escribano con el siguiente rótulo en portada: Doña María Pacheco, muger de Padilla. Tragedia española en tres actos. Su autor Don Ignacio García Malo $^{6}$.

No encontramos, sin embargo, noticias impresas de su existencia hasta 1789; primero se hablará de sus representaciones los días 7 y 8 de septiembre, en el Diario de Madrid; y del libro pocas fechas después, el 11 del mismo mes, gracias a un breve anuncio en la Gaceta de Madrid: «Doña María Pacheco, muger de D. Juan de Padilla: tragedia original Española en tres actos, por D. Ignacio Garcia Malo. Se hallará en la Libreria de Castillo, frente á S. Felipe; y en la de Barco, carrera de S. Gerónimo».

A partir de ahí, aparecerá ya catalogada en diversos repertorios. Por ejemplo, en la Biblioteca periodica anual para utilidad de los libreros y literatos (tomo $2 .^{\circ}$, año de 1789, núm. VI, Madrid, Imprenta Real, p. 25), donde en el apartado relativo a García Malo se comunica la publicación: «Doña Maria Pacheco, muger de D. Juan Padilla: Tragedia original Española en tres actos... Lib. de Castillo». Otra vez es recogida por Joaquín Ezquerra en su Índice, confeccionado junto con Pedro Pablo Trullench: « $\mathrm{D}^{\mathrm{a}}$. Maria Pacheco muger de Padilla.- Septe 89 pte. $2^{\mathrm{a}} »^{7}$.

5 El dictamen del censor quedó redactado así: «M. P. S.».- «De órden de V.A. he exâminado la Tragedia intitulada $D^{a}$. María Pacheco, compuesta por Dn. Gil Cano Moya; y no he advertido en ella defecto alguno que pueda servir de obstáculo para su publicacion; pues aunque toda la Tragedia se funda en una rebelion de la Ciudad de Toledo en tiempo de las Comunidades de Castilla, el Autor ha procurado inspirar horror á la rebeldía, y dexar castigada la traicion, sin lo qual habría inconveniente en exponer al Público unos exemplos de semejante naturaleza. Agrégase no contener este Drama máxima alguna que se oponga á las buenas costumbres y Regalías de Su Mgd: por lo que V. A. podrá, si es de su agrado, conceder al Autor la licencia qe. solicita para imprimirle».- «Mádrid á 15 de Octe. de 1787».- «Tomas de Yriarte» (firmado y rubricado).

6 Va escrita esta tragedia en verso endecasílabo, sin rima en los impares y con ella asonante en los pares, manteniéndose invariable por actos, y según la siguiente disposición vocálica: las diez escenas del primero (págs. 1-31), e-o; las doce del segundo (págs. 32-68), e-a; y las trece del último (págs. 68-95), e-o. Editado por la Viuda de Miguel Escribano, consta el libro (que en adelante nombraremos sólo como Doña María Pacheco, y que será por el que siempre citemos) de las siguientes partes: «Prólogo» (6 páginas sin numerar; o, más exactamente, parece estar foliada alguna, por signarse con el 3 la primera hoja y con el 4 la tercera; la última, que habría de llevar el 5 , aparece sin número al pie) + «Argumento» (3 pp. s. n.) + «Nota» (3 pp. s. n. ) + «Personas» (1 p. s. n.) + 95 páginas. No es por lo tanto totalmente preciso el dato de Dionisio HidaLGO cuando registra: «XIV-96 págs» (Boletín bibliográfico español, Madrid, Imprenta de las Escuelas Pías, 1860, tomo I, p. 176). La cifra de 96 páginas es también recogida por Francisco AguiLAR PiÑal en su insustituible Bibliografía de autores españoles del siglo XVIII, Madrid, CSIC, 1986, vol. IV, p. 135.

7 Yndice Alfabético de las Comedias que se han representado en los Coliseos de Madrid desde el dia $1^{\circ}$. de Enero de 1784, dispuesto por Dn. Joaquín Ezquerra y Dn. Pedro Pablo Trullench, Compositores del Memorial literario, instructivo y curioso, que desde el mismo mes se empezò â publicar en esta Corte (Biblioteca Nacional de Madrid, en adelante BNM), ms. 14.758, h. s. n.). Precisamente el Memorial literario (t. XVIII, 1789), 
Joaquín Arteaga la menciona en dos ocasiones en su Índice, si bien en la primera de ellas figura como «Doña Mariana Pacheco» ${ }^{8}$.

Parecidamente, Manuel Casal y Aguado tampoco consigna con exactitud el nombre en su Resumen clasificado del $n^{o}$ de comedias de Casal: «Pacheco (D. Marí.)» ${ }^{9}$.

Manuel Ovilo y Otero, por su parte, nos añade ya alguna información adicional sobre la obra, pero se confunde en el año de edición: «La mujer de Padilla. Doña María Pacheco, trajedia original de D. Ignacio García Malo. Representada solas dos noches en el teatro dela Cruz, la primera el 7 de setiembre de 1789. Madrid. Imp. dela Viuda de Escribano, 1786» ${ }^{10}$. En similares términos (aunque bien fechada) nos la muestra Hartzenbusch, quien, entre las pertenecientes a 1789, apunta: «7 de Setiembre. C. La muger de Padilla, Da María Pacheco, trag. orig. de D. Ygnacio Garcia Malo. Tuvo solas dos representaciones» ${ }^{11}$.

Más por extenso comenta Ramón del Toro la composición del joven dramaturgo $^{12}$, metiéndonos de lleno en un asunto de los más principales que se puedan plantear respecto de esta pieza: el de la finalidad política del autor al escribirla.

\section{La aparente intencionalidad política de la obra}

Comienza del Toro plasmando el comentario que el Memorial literario había dedicado a la Pacheco en 1789 (tomo XVIII) —en el que se explicaba que el vulgo no se había entusiasmado con la pieza por no ser afecto a ese tipo de teatro arreglado al arte—-, para disentir en los términos siguientes:

No debieron los redactores del Memorial literario atribuir á tales causas el desagrado con que el público acogió la obra del Sr Garcia Malo ¿Porqué algunos

periódico que dirigía Ezquerra, contiene una reseña dedicada a la obra de Malo sobre la que volveremos más adelante.

8 Yndice alfabetico de Comedias, Tragedias y demas piezas del Teatro Español formado por D.—, folios 115r. y 252v. (BNM, ms. 14.698).

9 BNM, ms. 17.450 (14), h. s. n., entre otros papeles suyos. La cita, asimismo, en el Índice de Comedias antiguas, y raras, y no comunes. Con una sucinta narración analítica de su mérito, y assumpto de que tratan. De D. Lucas Alemán y Aguado, tal y como consigna Francisco Agullar PiÑal, en «Noticia del Indice de Comedias de Manuel Casal y Aguado», tirada aparte de los Cuadernos Bibliográficos (Madrid), vol. 28 (1972), pág. 4.

10 Catálogo biográfico bibliográfico del teatro moderno español, desde el año 1750 hasta nuestros días, por D.—, t. I (BNM, ms. 14.616, f. 432r.).

11 Juan Eugenio Hartzenbusch, Catálogo cronológico de las piezas dramáticas publicadas en España, desde el principio del siglo XVIII hasta el año de 1831 (BNM, ms. 20.846-1).

12 Ramón del Toro y Durán, Catálogo, BNM, ms. 3.566, n. 16, pags. 38-39. 
años despues obtuvo tan brillante éxito La Viuda de Padilla de D Francisco Martinez de la Rosa? Porque este, comprendiendo el carácter del pueblo español, tan amante de sus glorias nacionales, presentó á la inmortal heroina adornada con todas las virtudes que podian enaltecerla y que efectivamente tuvo. Si Garcia Malo hubiera obrado del mismo modo, aunque los tiempos en que escribió eran muy diferentes de los anormales de que supo aprovecharse tan oportunamente Martinez de la Rosa para la composicion y representacion de su tragedia, los españoles, aun los más ignorantes, que siempre con maravillosa perspicacia han comprendido y amado la verdad, no hubieran escaseado los aplausos á la Doña Maria Pacheco, si la suspicacia del gobierno hubiera permitido, cosa bastante dificultosa, que saliera á luz en tales condiciones, pues apesar de haber presentado el autor á Doña Maria dominada por todas las malas pasiones que podian hacer odiosa la causa que defendió, al fin fué prohibida esta tragedia por real órden de 14 de Enero de 1800.

Ya en la Memoria dirigida a Le Brun el 23 de diciembre de 1792 José Marchena había aseverado: «El pueblo español se acuerda siempre de sus Cortes, y en el año 89 el público recibió con la más violenta indignación una pieza en que se ultrajaba la memoria de $\mathrm{D}^{\mathrm{a}}$ María Coronel» ${ }^{13}$.

Un nuevo testimonio en favor del servilismo de la tragedia hacia el poder real lo obtenemos de Serrano y Sanz que, interpretando pro domo sua el dictamen del censor, señala:

Otra condición que había de llenar la obra dramática, a más de las consabidas unidades, era un espíritu de sumisión completa a las autoridades, especialmente a la del Monarca; por esto alabó D. Tomás de Iriarte en Doña María Pacheco, tragedia de D. Gil Cano y Moya, seudónimo de D. Ignacio García Malo (1787), que, si bien toda la obra se fundaba «en una rebelión de la ciudad de Toledo en tiempos de las Comunidades de Castilla, el autor ha procurado inspirar horror á la rebeldía, y dejar castigada la traición, sin lo cual habría inconveniente en exponer al público unos ejemplos de semejante naturaleza» ${ }^{14}$.

13 Se cita por Marcelino Menéndez y Pelayo, Estudios y discursos de crítica histórica y literaria, t. IV, Santander, Aldus, 1942, pág. 136. Para verificar la confusión de Marchena con el apellido de la protagonista y confirmar, por ende, que se estaba refiriendo a María Pacheco, hay que señalar que ese mismo error se le detecta en A la nación española, donde la identificación es inequívoca: «Manes de Padilla, y tu, grande alma de doña María Coronel que lloras en la tumba la cobardìa de tus descendientes, inspira à los españoles aquél valor con que defendiste en las murallas de Toledo las ultimas reliquias de la moribunda libertad» (en Abate Marchena. Obra en prosa, prólogo y notas de Fernando Díaz-Plaja, Madrid, Alianza, 1985, pag. 163).

14 Manuel Serrano y Sanz, «El Consejo de Castilla y la censura de libros en el siglo XvIII», Revista de Archivos, Bibliotecas y Museos (Madrid, Tip. de la Revista de Archivos, Bibliotecas y Museos), t. XV (2.

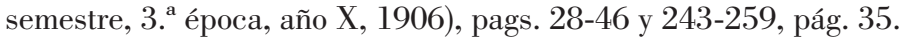


De semejante entender se muestra Andioc entrando ya en un análisis más a fondo del libro. Así, con motivo de las palabras finales que María dirige a su hijo exhortándole a acatar siempre los mandamientos del rey y de sus ministros, comenta esto:

Dans la mesure où l'on ne discute pas les décrets de la providence, justes par essence, le citoyen se voit invité à renoncer à tout esprit critique à l'égard des décisions du monarque, donc à se laisser gouverner sans chercher à comprendre, autrement dit, à se dépolitisier; la réponse à cette invitation, c'est précisément l'indifférence politique qu'affichent bien souvent, comme nous le verrons, ceux qui vivent, ou veulent vivre, en paix avec le régime ${ }^{15}$.

Y, tal vez apoyadas en la autoridad de tan ilustre estudioso del siglo XVIII, otras opiniones posteriores van a incidir en esa dimensión «absolutista» de la obra $^{16}$.

También para Mendoza Fillola el texto de García Malo puede considerarse modelo proclive a la autocracia monárquica: «Quizá sea la mediocre obra de Ignacio García Malo, notable helenista y traductor de la Iliada en endecasílabo, la tragedia $D^{a}$ María de Pacheco, viuda [sic] de Padilla, por tratar de un asunto

15 René Andioc, Sur la querelle du théâtre au temps de Leandro Fernández de Moratín, Burdeos, Feret \& Fils, Éditeurs, 1970, pag. 320. Más tarde repetirá estas ideas en Teatro y sociedad en el Madrid del siglo XVIII, 2. ${ }^{\mathrm{a}}$ ed., corregida y aumentada, 1987 (1. ${ }^{\mathrm{a}}$ ed., 1976), Madrid, Castalia, pag. 292.

16 Éste era el sentido real de nuestras palabras cuando nos referimos a tal concreto asunto en un trabajo anterior (vid. Felipe Rodríguez Morín, «Sobre el pretendido absolutismo de Doña María Pacheco, de Ignacio García Malo», en Estudios dieciochistas en homenaje al profesor José Miguel Caso González, Oviedo, Instituto Feijoo de Estudios del Siglo XVIII, 1995, pags. 277-283, pags. 277-278): el de declarar el ascendiente de René Andioc en materia de teatro dieciochesco, y la consiguiente repercusión en otros autores que con posterioridad opinaron sobre el tema, y a los que pudo servir como punto de referencia el juicio del hispanista francés sobre este particular. Valgan los siguientes comentarios en ejemplo breve de dicha hipótesis; así en el Manual de literatura española. V. Siglo XVIII (Felipe B. Pedraza Jiménez y Milagros Rodríguez Cáceres, Tafalla, Cénlit Ediciones, 1981, pag. 308), se puede leer: «Aunque el personaje histórico se exilió a Portugal, García Malo hace morir en escena a María Pacheco mostrándola arrepentida de sus malas acciones. Queda así reforzada la apología del absolutismo y el rechazo de la rebelión popular. Esta actitud política disgustó a buena parte del público que veía en los comuneros a los héroes de la libertad». Por su parte, Froldi manifiesta acerca de Doña María Pacheco que «la tragedia se convirtió en una glorificación total del absolutismo monárquico» (Rinaldo FroLDI, «El teatro», en Historia de la literatura española, vol. II: Desde el siglo XVIII hasta nuestros días, Madrid, Cátedra, 1990, pag. 883). Y Sala Valldaura, refiriéndose a ella, habla de «aceptación sin reservas del absolutismo regio» (Josep María Sala Valldaura, «La felicidad social como virtud en la tragedia neoclásica», Castilla. Estudios de Literatura, núm. 19 [1994], pags. 171-186, pag. 177). Más recientemente volverá a insistir Sala Valldaura en esta misma tesis, a lo largo de su libro De amor y política: la tragedia neoclásica española, Madrid, Consejo Superior de Investigaciones Científicas, 2005, y especialmente cuando, hablando de «los ideales absolutistas», apostilla: «[...] los mismos que proclama hasta la saciedad Doña María Pacheco, de García Malo» (pag. 403). 
tan delicado, la que de una manera exagerada nos sintetiza la concepción de la infabilidad absolutista ${ }^{17}{ }$.

Menos tajante, respecto al supuesto empeño por inculcar dicha doctrina, se nos representa Guillermo Carnero cuando, sintetizando el contenido, evita la palabra absolutismo: «El mensaje conservador de la tragedia es obvio, más allá de las alegaciones doctrinales de D. Pedro López y el marqués de Mondéjar. No existen posibles razones ideológicas que justifiquen una rebelión ${ }^{18}$.

El propio D. Ignacio había públicamente reconocido ante sus lectores, precisamente en el mismo año que se imprimió la Pacheco, su devoción cuasi religiosa por la figura real, tal y como en el «Discurso preliminar» a la Ilíada se proclama:

El respeto á los Reyes lo enseña Homero con unas ideas grandes y nobles en dos palabras: Su dignidad les viene de Júpiter; y mas adelante, Júpiter mismo es el que da á los Reyes el cetro, y los hace depositarios de las leyes para gobernar los pueblos. Esto manifiesta quan sacras, veneradas é inviolables deben ser la magestad y la persona de los Reyes: que resistir á su autoridad, es resistir á la de Dios; y que asi como su poder emana unicamente de Dios, solo Dios puede quitarselo. ¡Admirables maxîmas! ¡ideas sublimes y magníficas! Estas y otras muchas que se hallan

17 Antonio Mendoza Fillola, «Aspectos de la tragedia neoclásica española», Anuario de Filología (Barcelona: Facultad de Filología de la Universidad de Barcelona), 1981, pags. 369-389, pag. 385. Contraponiendo esta producción de Malo a La viuda de Padilla, Renata Londero se acoge a idéntico sentir: «[...] in García Malo, il pentimento di María è una silloge della filosofia assolutista; in Martínez de la Rosa, il suicio della vedova si configura come una testimonianza estrema dell’anelito alla libertà della patria e dell’individuo» (Renata LoNDERo, «Scorci della guerra de las comunidades nella tragedia neoclasica: Ignacio García Malo e Martínez de la Rosa», Il Confronto Letterario, núm. 24 [noviembre 1995], Schena Editore, pags. 599-612, pag. 610). Y continuando con el parangón entre dichas dos obras, Aznar Soler adopta, igualmente, esa misma postura: «La Historia de España proporciona por tanto a ambos autores un mismo tema dramático, pero su interés estriba en que ellos lo interpretan desde perspectivas ideológicas y políticas muy diferentes: defensa apasionada del absolutismo monárquico en García Malo y exaltación no menos apasionada de la libertad en Martínez de la Rosa» (Manuel Aznar SoLER, «Historia y política en dos tragedias neoclásicas: Doña María Pacheco, de Ignacio García Malo, y La viuda de Padilla, de Francisco Martínez de la Rosa», en El mundo hispánico en el siglo de las luces, t. I, Madrid, Editorial Complutense, 1996, pag. 418). También Pérez Magallón, aprovechando el contraste entre ambas piezas, considera la de Malo radicalmente proclive al ensalzamiento monárquico: «El eje de ese discurso está claro: a los reyes se les debe obediencia absoluta, idea en la que coincide con la exaltación de la obediencia como el rasgo esencial que debe caracterizar al vasallo presente en otras obras» (Jesús Pérez Magallón, El teatro neoclásico, Madrid, Ediciones del Laberinto, 2001, pag. 145).

18 Guillermo Carnero, «Doña María Pacheco (1788) de Ignacio García Malo y las normas de la tragedia neoclásica», pag. 111 (idénticas palabras en su edición de la tragedia, Madrid, Cátedra, 1996, pag. 32). Por otra parte, esta pieza es incluida por Manuel Gómez en su Diccionario del teatro, si bien con alguna no muy exacta precisión, pues en la entrada correspondiente a nuestro autor apunta esto: «Escritor español del siglo XIX [sic]. Se le debe una sola obra teatral, la tragedia Doña María Pacheco, dada a conocer en 1788» (Manuel Gómez García, Diccionario del teatro, Madrid, Akal, 1997, pag. 347). 
en Homero, respectivas á la veneracion que se debe tener á los Reyes, y conforme á lo que dice San Pablo ${ }^{19}$.

A pesar de que de alguno de los testimonios expresados pudiera inferirse que un palmario y, por encima de cualquier otra pretensión, destacable afán por defender a capa y espada el poder omnímodo de la Corona condujo y animó al autor, juzgamos mucho más compleja la cuestión, con visos de insoluble por los datos manejados, ya que, desdiciéndose unos a otros, o siendo susceptibles de interpretaciones opuestas, nos arrastran en más de una ocasión a la incertidumbre.

En sí, la obra impresa se abre con un «Prólogo», cuyo arranque mismo es claro exponente del respeto del escritor por las teorías poéticas neoclásicas: «La opinion mas comun entre los Maestros del Arte Dramatica, es que el asunto para la Tragedia debe tomarse de un hecho histórico». Y, en la misma línea de componer con arreglo a la normativa neoclásica, prosigue en su introito al poco: «Buscaba yo para hacer una Tragedia original un hecho de nuestra Historia ${ }^{20}$, que me subministrase los recursos necesarios para sacarla sin las monstruosidades è irregularidades que traen consigo algunos hechos (aunque memorables) por la multiplicidad de incidentes» ${ }^{21}$.

19 La Ilíada de Homero, traducida del griego en verso endecasílabo Castellano por D. Ignacio Garcia Malo, Madrid, Pantaleón Aznar, 1788-1789, pags. LXXXII y LXXXIII. Acerca de este concreto punto, Mirella Romero no duda en afirmar lo siguiente: «García Malo va a desplegar todos los argumentos necesarios para justificar, a través de Homero, los pilares del absolutismo» (Mirella Romero Recio, «Religión y política en el siglo XVIII: el uso del mundo clásico», Ilu. Revista de Ciencias de las Religiones, vol. 8 [2003], pags. 127-142, pags. 136-137).

20 Anota, a la sazón, Carnero los referentes impresos de que se sirvió Malo para fraguar su obra: «Para componer su tragedia, Ignacio García Malo se inspiró fundamentalmente en las cuatro letras y el Razonamiento hecho en Villa Bráxima que dedicó a las Comunidades fray Antonio de Guevara en sus Epístolas familiares, y ocasionalmente en la Historia de la vida y hechos del Emperador Carlos V de Prudencio de Sandoval» (Ignacio García Malo, Voz de la Naturaleza [Lisandro y Rosaura. Teodoro y Flora. La desventurada Margarita. Amadeo y Rosalía. Flavio e Irene. Anselmo y Elisia. El brigadier y Carlota. El benéfico Eduardo], selección, estudio preliminar y notas de Guillermo Carnero, Madrid, Támesis, 1995, pag. 69). El mismo Carnero en otro de sus trabajos («Introducción» a su edición de Doña María Pacheco, mujer de Padilla. Tragedia, Madrid, Cátedra, 1996, pag. 34) comenta acerca del particular «cómo en ocasiones García Malo versifica literalmente la prosa de Guevara».

${ }^{21}$ A la hora de escoger tema y protagonista del mismo, Malo parece tener en cuenta los gustos de la gente que acude a los teatros. No en vano, Fernández Cabezón afirma al respecto: «Estudiadas dieciséis piezas significativas, llegamos a la conclusión de que esta proliferación de mujeres fuertes en los escenarios españoles puede responder a la relevante presencia femenina en los coliseos de la época; a las damas del siglo ilustrado les gusta — a juzgar por los éxitos teatrales de las comedias recogidas— ver actuar a estas heroínas en unas gestas semejantes a las realizadas por los varones, les atrae que sean ensalzadas por su fortaleza y valentía, que algunas defiendan sus derechos, a modo de compensación por la inferioridad social que deben padecer en la vida cotidiana» (Rosalía Fernández CABEZón, «La mujer guerrera en el teatro español de fines del siglo XVIII», Anuario de Estudios Filológicos, vol. XXVI [2003], pags. 117-136, pag. 117). 
De este respeto por los cánones neoclásicos nos había hablado ya el propio Malo un par de años antes, en 1786, con palabras referidas a su otra tragedia, Guillermo de Hanau:

No pretendo persuadir que no tendrá algunas imperfecciones (porque sería casi la primera que no las tuviese) solo sí presento este ensayo, para observar rigidamente las tres unidades; esperando que algun otro de superior talento al mio, procurará aplicarse à perfeccionar este modo de hacer Tragedias y Comedias à que se han dedicado muy poco la mayor parte de nuestros Poetas, queriendo mas agradar à los ignorantes, que à los hombres de buen gusto y erudicion $^{22}$.

Las pretensiones técnicas de Doña María Pacheco son un poco más adelante mezcladas con finalidades políticas:

Es dificil ceñir al rigor del Arte una accion tomada de la Historia, y vulgarizada en un Reyno, en que se hizo tan famosa como sensible; pero sin embargo he procurado seguirla con la mayor simplicidad, adornandola con sencillos episodios que de algun modo causasen en los Espectadores terror y compasion; y que al mismo tiempo excitasen el escarmiento, que merecen las acciones de esta clase, impropias de leales vasallos, ofensivas à Dios, injuriosas à los Soberanos, y perniciosas à las Repúblicas, en las que (siendo bien ordenadas) se executan en público los castigos para escarmiento de los malos.

Todo ello para concluir manifestando que ha subordinado las exigencias de la norma literaria a la intención ideológica: «Este ha sido el principal estímulo que me ha movido à formar esta Tragedia, persuadido de que, aun quando no estuviese enteramente arreglada à los preceptos del Arte, no dexaria de inspirar buenas idéas».

Suceden al «Prólogo» el «Argumento» y una «Nota» (ambos, como el «Prólogo», con las páginas sin numerar, según se ha apuntado); textos los dos en que -implícitamente en el primero y expresamente en el segundo- se confesará aquella falta de acomodo pleno de la pieza a las reglas dramáticas. De este modo, se puede leer en el «Argumento» que el autor hace «morir à Doña María arrepentida de sus delitos para el mayor escarmiento, y excitar el terror y

22 D. I. M. S. [D. Ignacio Malo Sánchez (el primer apellido de nuestro autor era el de García-Malo, y el segundo Sánchez)].- «Prólogo», sin paginar, al Guillermo de Hanau, Madrid, Blas Román, 1786. Acerca de la obediencia de García Malo respecto de estos requisitos, puede consultarse también la edición de Guillermo Carnero, ya citada, de la tragedia de Malo, pags. 39-48. 
compasion, propios de esta composicion Dramatica; pues de seguir literalmente la Historia no podria conseguirse» ${ }^{23}$. Y en la «Nota»:

En fin para conseguir mejor imprimir en los corazones de los Espectadores el aborrecimiento à las rebeliones que debe tener todo leal vasallo, tanto porque falta à Dios, faltando à la sumision y obediencia que debe prestar à su legítimo Soberano, como por los males y deplorables consecuencias que traen consigo, hace hablar à Doña Maria en la ultima Escena mas de lo que parece podria permitirle su actual situacion.

Previamente («Prólogo», h.s.n.), hablando del tema que del pasado rescató para formar su tragedia, había admitido igualmente el escaso sometimiento de aquél a la poética por la que pretende guiarse: «Bien conocí y conozco no ser de los mas acomodados, ni de los que dan mucho lugar los Maestros del Arte, por ser la pasion que tiene el mayor y principal movimiento el ódio, y aborrecimiento contra la Protagonista».

Tropezamos, de esta guisa, con el primer enigma: ¿por qué un hombre como García Malo, ferviente partidario de los preceptos neoclásicos, comprometido con la reforma profunda del teatro de su tiempo, se separa voluntariamente en algunas partes de su norte, por más razones que aporte en su descargo? ¿Por qué siempre que lo hace es a causa de un «objetivo» político, tal y como aduce? ¿Por qué, de toda la enorme panoplia de personajes históricos, elige uno que él mismo presume que causará antipatía en el lector o en el espectador?

¿Es posible conectar ese fenómeno con la doble presentación de la obra a censura y pensar, así, en una hipotética enmienda «a la absolutista» que le otor-

23 «Por lo tanto, la muerte no histórica de Doña María se introduce conscientemente para potenciar el impacto de la tragedia y su efecto didáctico» (Ignacio García Malo, Doña María Pacheco, mujer de Padilla, ed. de Guillermo Carnero, p. 48). Cierto es que existía un determinado margen de maniobra que facultaba al dramaturgo para alterar, en episodios secundarios, lo escrito por la historia: «Porque si bien es verdad que algunos hechos son muy notorios, no obstante el vulgo solamente tiene de ellos una noticia muy escasa y muy superficial. Además de esto, aun en las historias mismas no se hace siempre mención de todas las circunstancias, ni de todas las personas que intervinieron o verisímilmente pudieron intervenir en el hecho. Conque de esta manera, cuando el poeta sepa escoger para su tragedia un argumento capaz de ser labrado, siempre le queda entera su libertad, pudiendo variar el hecho, ya que no en lo principal y esencial, a lo menos en las circunstancias y en las personas menos principales» (Ignacio LuZÁn, La poética o reglas de la poesía en general y de sus principales especies. Primera edición completa de ambos textos dieciochescos [1737 y 1789], ed., prólogo y glosario de Russell P. Sebold, Barcelona, Labor, Textos Hispánicos Modernos, 1977, pag. 455). Pero no parece que al caso presente se satisfagan los requisitos reclamados por Luzán, puesto que aquí la modificación más importante — asesinato de María en lugar de fuga a Portugal— se efectúa en el personaje central, y eso como consecuencia de una contienda harto popular, «vulgarizada en un Reyno, en que se hizo tan famosa como sensible» («Prólogo» a Doña María Pacheco, mujer de Padilla, 1788), y cuyo final, por tanto, podía ser conocido por algunas gentes. 
gara el plácet un año después del primer intento, y que tal concesión le hubiera obligado a saltarse algunos puntos del canon dramático y a corregir «para mal» el carácter de la protagonista ${ }^{24}$ ?

Se hace menester abrir aquí un inciso para indicar que la obra ha llegado a nosotros en dos versiones, similares, pero no idénticas. Una de ellas, la impresa, ya reseñada; la otra, en forma manuscrita, probablemente posterior a aquélla y que, quizá, fue la que subió a las tablas ${ }^{25}$.

Carece esta última, como propia de la representación y no de la lectura, de los exordios y explicaciones («Prólogo», «Argumento» y «Nota») de la editada, así como de la enumeración de escenas y de 209 versos (salvo error en el cómputo), que le fueron suprimidos probablemente por arbitrio de la compañía teatral ${ }^{26}$; cosa que no era nada extraña, pues, como afirma Andioc, «fuera de que, por no haberse instituido los derechos de autor y tener el comediógrafo que venderle su obra a la compañía, ésta se convertía en propietaria del manuscrito adquirido, pudiéndolo modificar o incluso acortar para no exceder el tiempo global de la función» ${ }^{27}$.

Además de acomodar el texto a las necesidades de la representación mediante el descarte de versos sin contenido específico, se aprovecha esa reducción para talar aquellos pronunciamientos o pasajes que podían resultar más conflictivos. Así, de los parlamentos de María, aparte de eludir el requerimiento de independencia de Castilla (II, 12, pág. 65), o de frases que reiteran su lealtad a la causa, se evita, por dos veces, la expresión «despótico manejo» endosado a los flamencos que gobiernan España (I, 3, pág. 12 y III, 10, pág. 85). De idéntica

24 No nos atrevemos ni siquiera a insinuar que la elección del tema y del personaje principal quisiera ser una especie de homenaje de García Malo a la Casa de Villena, de cuyo primer marqués era nieta María Pacheco, linaje a quien tan agradecido debía sentirse así nuestro autor como su familia, pues dependiendo por merced real su localidad natal, Castillo de Garcimuñoz, del señorío del marqués de Villena, fueron nombrados tanto su abuelo como su padre alcaldes por el estamento noble, y el propio Ignacio alguacil mayor por el mismo estado noble en 1777, año en el que el marquesado recaía en Felipe López Pacheco de la Cueva (AHN, Estado, Orden de Carlos III, expediente 1.119, f. 180r.-v.). De haber sucedido así, y de haber resultado aquélla la intención de García Malo, podría deducirse que su pretensión inicial no habría sido, desde luego, la denostación del personaje central de Doña María Pacheco.

25 El ejemplar que hemos manejado se encuentra en la Biblioteca Histórica de Madrid (como I. L. MCCLELLAND oportunamente se encarga de señalar en Spanish drama of pathos. 1750-1808, vol. I, Liverpool University Press, 1970, pag. 258), sig. 1-47-7, y recoge el nombre de los actores que desempeñaron los respectivos papeles; siendo, por cierto, la famosa Tirana quien encarnó a la protagonista. Figura como título de dicho libro el de «La Muger de Padilla D María Pacheco. Tragedia Española» (así, sin subrayar); y debajo: «Acto $1^{\circ}$. Apto. $1^{\circ}$ » (sin mención de autor). Y, consecutivamente, «La Padilla, Acto $2^{\circ}$, Apto. $1^{\circ}$ » «La Padilla, Acto $3^{\circ}$, Apto. $1^{\circ}$ ».

2698 versos le son eliminados a López, 62 a María, 28 a Matilde, 16 a D. Íñigo y 5 a otros.

27 René Andioc, «Organización y características de la actividad teatral», en Guillermo Carnero (coord.), Siglo XVIII (I), en Historia de la literatura española, dirigida por Víctor García de la Concha, Madrid, Espasa-Calpe, 1995, pág. 301. 
forma, y como no podía ser de otra suerte a la altura de septiembre de 1789, se le cercena la alusión a un teórico auxilio de su situación por parte de los franceses (III, 10, pág. 85):

Francia ofendida está, y su justo ceño

Puede vengar ahora en que ha quedado

Sin fuerzas, ni dinero todo el Reyno.

Parecidamente a lo que con su señora, ocurre con Matilde, dado que también a ella se le quita de la boca el término despotismo (II, 10, pág. 60) y las dos referencias a una alianza con Francia (II, 10, págs. 59 y 61), de la que se devela inspiradora:

Dad parte à los Franceses, que ofendidos

Aun en sus pechos ínclitos conservan

A aquella sedicion que hubo en Navarra,

Y ellos enviarán quien nos defienda

De tantos enemigos poderosos.

Hasta que vengan las Franceses huestes,

Que acampadas están en las fronteras.

A la vez, es despojada de catorce versos (II, 10, págs. 61-62) en los que mostraba patriotismo y fidelidad hacia su causa.

Ni siquiera el bando imperial se ve libre de esta poda. Al revés, es López el personaje al que más intervención se le descuenta. Entre otros muchos lances, entresacaremos aquel en que le es acallado un determinado pensamiento sobre la confiscación comunera de los bienes de las iglesias (I, 8, pág. 21):

¡Oh sacra Religion! ¡oh Fé Christiana!

¿Quién podrá ser tu entivo y fundamento,

Si los mismos Christianos te abandonan,

Quando ensalzar tu nombre prometieron?

O cuando reconoce el poder de convocatoria, aun póstumo, de Juan Padilla, su hijo (II, 9, pág. 54):

Va añadiendo delitos à delitos.

Toda esta rebelion ella acrecienta, 
Recordando la muerte de su esposo,

Que la plebe, aunque muerto, lo venera.

De todos modos, los fragmentos borrados a López no son, por lo general, singularmente significativos.

Finalmente, y para terminar ya de comentar el referido manuscrito, hay que dejar constancia de que, de los dieciséis versos elididos a Íñigo, diez conforman un lamento sobre la inconstancia del vulgo hacia sus líderes (III, 5, pág. 77); y respecto de este punto no deja de sorprender que sea él, después de haber cambiado de facción, quien precisamente pretenda sentar doctrina al respecto.

\section{Cualidades morales de los personajes y otros diversos elementos relacionados con la finalidad perseguida por el autor.}

Por lo que se refiere a los personajes, individualmente considerados, ha de significarse que es María Pacheco, y su empeño por no rendir Toledo a las tropas del rey, el eje indiscutible sobre el que gravita la tragedia; y lejos de ser presentada la protagonista con rasgos negativos, como podría pensarse por resultar la encarnación del bando sedicioso, se nos aparece revestida de las más variadas y preciosas virtudes, quedando la del patriotismo como la más acusada:

Pues como sea à libertar la Patria

Ya todo lo demás importa menos ${ }^{28}$.

Y por ese ideal estará dispuesta, según repetidamente asegura (II, 1, 5 y 7 , págs. 34, 41 y 47), a dar su vida:

El amor de la Patria me aconseja,

$\mathrm{Y}$ antes daré la vida que rendirme:

Busco su libertad aunque perezca

(II, 8, pág. 52)

28 Doña María Pacheco, 1788, I, 5, pág. 17. Tal actitud es llevada hasta las puertas de la muerte. Y así proclama María, en situación tan particular que confiere un baño de autenticidad a sus palabras (pág. 94): «iAh patria! tú ocasionas mi desgracia: / Por tu amor, por tu causa yo fallezco; / Pues fuiste sobre todo preferida, / Siendo de mi pasion mayor objeto». Lo mismo ha de valer para su esposo, ya difunto, espejo en el que ella se mira, y del que recuerda que el ánimo que le impulsó fue el «De defender la Patria, y el Estado» (pág. 15). 
Del compromiso total de la protagonista con su empresa dan fe los términos con que reprocha al marqués de Mondéjar, su hermano, el que siga las banderas contrarias:

Calla, indigno enemigo de tu patria.

(II, 7, pág. 46)

Quitate de mi vista, aleve, iniquo

Destruidor de la patria, infame fiera.

(II, 7, pág. 47)

Mas bien serás tú, traydor iniquo,

Cuya vana ambicion es tan perversa,

Que ofendiendo à tu patria y à tu sangre,

Aniquilarme quieres con cautelas ${ }^{29}$

(II, 8, pág. 48)

La fidelidad a sus principios es otra de las particularidades que adornan a la heroína, resaltada aún más en el contraste con otras conductas, verbigracia la que adopta al final el vulgo o la que vergonzosamente ostenta un miembro del propio estamento de María: D. Íñigo ${ }^{30}$. Por eso, ante su fortaleza, de nada valen los apaños que le ofrecen, caso del negocio que le sugiere López de conservar la vida, ni bienes ni privilegios futuros por deponer su acción y prometer acatamiento a Carlos V; a su suegro responde así:

Yo sigo el exemplar de mi marido,

$\mathrm{Y}$ aquel solemne, $\mathrm{y}$ justo juramento

Con que ofrecí seguir aquesta Liga

Hasta perder la vida. Estad en esto,

$\mathrm{Y}$ no propongais pactos tan viles.

(III, 3, pág. 73).

29 Poco antes (II, 7, pág. 44), al explicarle Mondéjar que venía a librarla, le había ya espetado: «¿Cómo, vil, arrogante, fementido, / Delante de mi vista te presentas, / Quando aun tu nombre solo me horroriza, / Y el ser hermana tuya me avergüenza».

30 Este mezquino sujeto, gobernador de Toledo, que en un principio (I, 7, pág. 19) exclama: «La Ciudad à mi cargo se halla toda: / Me toca defenderla con esfuerzo, / Y derramar la sangre que me alienta / Por mí mismo, por ella, por mi empleo», dirá, a solas (III, 5, pág. 77), ese mismo día (pues la acción se desarrolla en dicho espacio temporal), una vez tomado Toledo por los imperiales, y ante la petición del pueblo de que se dé muerte a María: «Valgame Dios! ¡qué tristes consecuencias! / Aturdido me tiene este suceso; / Aunque yo del peligro estoi ya libre, / Porque presté à mi Rey el juramento / De seguir sus vanderas, y partido, / Y dexar à los vandos Comuneros». 
Porque lo cierto es que a D. ${ }^{a}$ María le importa mucho más el honor, gloria que dimana del cumplimiento del deber:

Quando vierta mi sangre por la Patria

Satisfago à mi honor, que es lo que debo

(I, 3, pág. 13),

y que trasciende a las sucesivas generaciones (I, 10, pág. 30):

Por la sangre que corre por mis venas,

Y el honor que heredé de mis abuelos,

Os ofrezco, patricios, no dexaros ${ }^{31}$.

Junto a los enumerados, también el valor es mérito con el que se ve favorecida. Evidente a través de sus acciones durante toda la obra, es puesto de relieve a menudo. Como en aquella conversación que mantiene con Matilde, después de haber sido herida en batalla (II, 4, págs. 39-40):

DoÑa Maria.

Es leve, y no me pasma, ni consterna.

Matilde.

Pero puede tener malas resultas.

DoÑa MaRia.

No importa, sufriré las que me vengan.

Esta fuerza de ánimo que siente y comunica le es reconocida, bien que a su pesar, por López y Sosa, oponentes suyos, quienes, respectivamente (II, 2, pág. 37 y II, 3, pág. 37), deploran de la siguiente forma sus consecuencias:

Armada de furor, por las esquadras

Corre, inspira valor, manda, gobierna,

Y delante de todos sus soldados

Con la espada en la mano se presenta.

31 Por eso debemos discrepar de la opinión de Berbel Rodríguez cuando sitúa el afán de venganza como motor de la actitud belicosa de María: «[...] el deseo obstinado de vengar al marido muerto, junto al estado de necesidad, le impulsa al error de confiar en Matilde y de continuar la rebelión armada contra Carlos V» (José J. Berbel Rodríguez, Orígenes de la tragedia neoclásica española [1737-1754]. La Academia del Buen Gusto, Sevilla, Universidad de Sevilla, 2003, pág. 188, n. 45). 
Señor, toda Toledo comovida [sic],

Siguiendo los consejos y las huellas

De vuestra infeliz hija, su caudillo,

Que le infunde valor con su presencia,

Ahora acaba de hacer una salida

Con el mayor arrojo y con violencia.

Y por si fuera poco, aparte de todas sus virtudes guerreras, late en el corazón de María una ternura honda y sincera que preferentemente aflora en su mundo íntimo, al retirarse de sus ocupaciones:

Aunque el mundo se oponga à mis designios,

Defenderé à Toledo hasta el extremo.

Pero ahora que sola me he quedado,

Sin que nadie interrumpa mis lamentos,

Es justo ¡Esposo mio! que yo llore

Tu muerte desgraciada, y fin funesto ${ }^{32}$.

(I, 4, pág. 14)

Y si en algunos momentos se exterioriza airada y vengativa:

Mi intencion se dirige à buscar medios

Para volver triunfante à la venganza

De tantos insolentes vituperios ${ }^{33}$

(III, 10, pág. 85),

o por completo indefensa (III, 10, págs. 86-87):

¡Ay de mí! ¿Qué he de hacer? ¡Oh suerte iniqua!

¿Por qué asi me persigues con tal ceño?

Mira qué soy muger desamparada

De todo humano bien. Piadosos Cielos

Amparadme en el lance que me hallo,

32 Asimismo la vemos romper en llanto ante el temor por la suerte que habrá de correr su hijo (II, 5, pág. 42) o desmayarse de dolor al enterarse de la muerte de su esposo (I, 2, pág. 7). De cualquier manera, la veta sentimental es mucho más débil en esta composición «política» que en otras de García Malo, tales como Guillermo de Hanau o la Voz de la naturaleza, por ejemplo.

33 Un poco más adelante (III, 10, pág. 87) se refrenda la idea del castigo a los realistas y a los comuneros traidores: «Que à pesar de mis males, seré siempre / Un rayo, que consuma con fuego / A todos los sequaces imperiales, / Y à todos los cobardes, y protervos, / Que me obligan à huir de estas murallas, / Pues para tal empresa valor tengo». 
la ilusión por un futuro diferente contribuye a que presto se sobreponga a esas dudas y quebrantos de moral que, por otro lado, la hacen más humana:

A Dios Patria infeliz, hasta que vuelva

A sacarte del duro cautiverio,

En que te han de poner las disensiones

De tantos fementidos extranjeros.

(III, 10, págs. 87-88)

Distinto atributo que se adscribe a María es, frente a lo que a primera vista pudiera parecer, el de la tolerancia; especialmente si se la compara con sus adversarios, pues a éstos de ninguna manera se les ocurren concesiones del tipo que otorga ella:

Seguid vuestro partido, defendedlo:

Yo el mio seguiré, venza quien pueda.

(II, 8, pág. 53)

Si es vuestro zelo justo, ò es injusto

A definir aqui no me detengo:

Ni si es el tema mio bueno, ò malo

Tampoco persuadiros yo pretendo.

(II, 3, pág. 74)

Esta ausencia de fanatismo y sinrazón había sido ya previamente anunciada con la oportunidad que se brinda a los insurrectos de fundamentar su alzamiento militar, y además por voz distinta a la de María, con lo que se esquiva la tentación de entender el motivo como nacido del más absoluto empecinamiento, cuestión que pudiera suscitarse de no haber habido quien la secundara en sus argumentos. Será, al efecto, D. Íñigo el encargado de exponer la causa de la rebelión (I, 3, pág. 11):

Señor no se formó por la avaricia,

fue solo por el bien de todo el Reyno.

Antes se exâmino el fatal estado

De toda la nacion. Los Comuneros

Por amor à la Patria se juntaron

En Avila, y no hallaron otro medio

Que el conseguir por armas, o por fuerza

Lo que facil no ha sido con los ruegos. 
Y hasta López, acérrimo defensor de la causa imperial, destinatario de las anteriores palabras, ha de admitir (I, 3, pág. 12):

No hay duda que han quedado en nuestro Reyno

Varios pueblos quejosos del desorden,

Con que lo han gobernado los Flamencos.

No se obviará tampoco (II, 10, pág. 59) el hecho de que el arzobispo de Toledo, primado de España, fuera, asimismo, un extranjero.

Además, la pertinacia de la protagonista — que, viéndolo todo perdido, se empeña en no deponer las armas - se justifica por el temor a las represalias que pudieran sufrir los habitantes de la plaza, olvidándose así, de nuevo en desprendido detalle, de su propia suerte:

Si llegase à rendirnos, usaría

De su indigno furor con inclemencia.

Me horrorizo al pensar en las desgracias,

Que si asi sucediese, nos esperan.

La sangre correria por las calles,

La Ciudad estaria en llanto envuelta,

Los viejos, las mugeres y los niños

Serian del furor victimas tiernas ${ }^{34}$.

(II, 1, pág. 33)

Prueba incuestionable de que María Pacheco no es una criatura odiosa se infiere de la postura hacia ella por parte de las personas que la conocen y que, aun ideológicamente enemigas, la quieren. Es el caso de su hermano, el marqués de Mondéjar, que, a pesar de que, como más adelante trataremos, propicia el intento de fuga de ésta con fines interesados, no es inmune a la separación; ello se demuestra en la despedida anterior a la, al cabo, fallida huida (III, 9, pág. 84), instante en que lo vemos embargado por la emoción:

A Dios, pues yá mi pena y sentimiento,

Ni para articular, ni mover el paso

Presta à mi corazon algun aliento.

34 Esta imagen radicalmente negativa que D. ${ }^{a}$ María posee de sus contrarios se detecta también más adelante, cuando al entrar para parlamentar un capitán del ejército real con la cara cubierta, y que a la postre resultó ser Mondéjar, comenta aquélla: «Veremos que maldad es la que intenta» (II, 6, pág. 43). 
Aunque será López quien más a menudo y por extenso revele — sobre todo en el tramo final de la obra, cuando mejor se palpa el peligro y la muerte- el profundo afecto que siente por María, a la que con frecuencia llama «hija $»^{35}$.

Otra muestra, de distinta índole esta vez, que puede dar testimonio del exquisito miramiento y «respeto» del escritor hacia la figura de María viene dada por los movimientos escénicos de ésta, en tanto que la eximen de adoptar posturas suplicantes, genuflexas ${ }^{36}$, o de que su cuerpo ruede por los suelos, cuando ocasiones hubo sobradas para esas coyunturas. Así, en lo concerniente a sus dos derrumbes físicos (fruto del dolor por el fallecimiento de su esposo y por su propia y mortal herida, respectivamente), observamos el recurso escogido por el autor, idéntico en uno y otro caso, para que la protagonista no dé con sus huesos en las tablas: «Cae desmayada en una silla» (I, 2, pág. 7), «Cae muerta en una silla» (III, 12, pág. 95).

Aparte de los señalados, en dos lugares más se nos concreta la pérdida de su verticalidad a través de las acotaciones, y en ambos se sigue manteniendo la misma «dignidad», pues en uno de ellos se repite la operación de sentarse (II, 6, pág. 43) y, en el otro, primero de la obra en este terreno, son eludidas expresiones del tipo agachar, doblar, etcétera, para reflejar la deferencia que guarda María hacia su suegro recogiéndole un papel que le fue al suelo (y que en nada menoscabaría tampoco su imagen, por corresponder a una acción bien normal y necesaria): «Saca el pañuelo para enjugarse las lagrimas, y se le cae la carta. La vé Doña Maria, va à alzarla, y conociendo que es letra de su esposo dice» (I, 2, pág. 6).

En conexión con este asunto de la composición de la figura de los personajes protagonistas, no resultaría ocioso traer aquí diversos ejemplos de cómo García Malo, en su colección narrativa Voz de la naturaleza, suele «castigar» la muerte de los malvados con la consiguiente caída al suelo ${ }^{37}$.

35 II, 2, pág. 36; II, 9, pág. 53; II, 9, pág. 55; II, 12, pág. 65; III, 2, pág. 72; III, 12, pág. 95. De igual manera, la escena 11 del acto tercero (págs. 88-90), especialmente en su tramo final, recoge la gran preocupación de López por su nuera.

36 Por contra, López sí que es captado en esa posición, precisamente ante María: «Arrodillase, y se levanta luego» (III, 3, pág. 74).

37 Voz de la naturaleza. Memorias o anécdotas curiosas e instructivas: obra inteligible, divertida y útil a toda clase de personas para instruirse en los nobles sentimientos del honor, despreciar varias preocupaciones injuriosas a la humanidad, amar la virtud y aborrecer el vicio a la vista de los ejemplos que contiene, t. I: Lisandro y Rosaura y Teodoro y Flora, Madrid, Pantaleón Aznar, 1787; t. II: La desventurada Margarita y Amadeo y Rosalía, Madrid, Pantaleón Aznar, 1787; t. III: Flavio e Irene y Federico y Beatriz, Madrid, Pantaleón Aznar, 1787; t. IV: El celoso indiscreto y El marido descuidado, Madrid, Pantaleón Aznar, 1788; t. V: Estanislao y Leonor, Madrid, Pantaleón Aznar, 1790; t. VI: Anselmo y Elisia y El vice-mariscal y Carlota (en adelante El vicemariscal y Carlota), Madrid, Pantaleón Aznar, 1792; t. VII: El benéfico Eduardo, Madrid, Imprenta de Aznar, 1803. En algunas ocasiones ese desplome se deduce del contexto, como ocurre en el caso de Juan, el burlador de Margarita, en la tercera novela de Voz de la naturaleza: «[...] al salir Don Juan de una 
En esta misma línea de intentar descubrir lo que juzgamos como cortesías del autor hacia la protagonista de Doña María Pacheco, no ha de olvidarse la progresión en el camino del sufrimiento con que, sucesivamente y sirviéndose de las acotaciones para su descripción, nos la va haciendo más entrañable ${ }^{38}$. Esta escala, que arranca de una situación claramente positiva: ( Sale Doña Maria ricamente vestida»; I, 2, pág. 5), conoce varios grados evolutivos antes de concluir en el fatal «Cae muerta en una silla» (III, 12, pág. 95). Los pasos de tal vía dolorosa son éstos: «Sale Doña Maria vestida de luto, y suelto el cabello» (I, 10, pág. 26); «Sale Doña Maria con su hijo de la mano, vestidos de luto, y en la otra un Estandarte negro, pintado en él con blanco un cadahalso» (II, 1, pág. 32); «Doña Maria, la qual lleva atado un pañuelo à un brazo lleno de sangre» (II, 4, pág. 39); «Sale Doña Maria, descompuesto el cabello, con esposas en las manos» (III, 3, pág. 72); y, por último, «Sale Doña Maria apoyada en los brazos de Haro y de Mondéjar, echando sangre $»^{39}$ (III, 12, pág. 90).

Hay que mencionar, por último — si bien para el autor acaso ocupe el tema el pedestal más alto—, cómo a D. . María se le concede el privilegio de descubrir su vertiente religiosa; y esto otra vez en un contexto que fácilmente se puede prestar a la interpretación contraria (por eso más atrás hablamos del carácter enigmático en la urdimbre de la fábula): el del despojo de las iglesias toledanas ${ }^{40}$ :

Y con profundo llanto he dirigido

Mis votos mas humildes y mis ruegos

Al Todo Poderoso, suplicando,

casa de juego en el mismo Madrid, le quitaron la vida á cuchilladas unos enemigos» (pág. 54). Aunque generalmente el derrumbe queda bien manifiesto, así cuando Guillelmo intenta violar a Irene, ella «coge la espada á Guillelmo, y en un pronto, sin poderse éste precaver, se le entra por el pecho, y cae sin aliento» (Flavio e Irene, pág. 58); «y dandole un fiero golpe con él [Carlota con un cuchillo al despreciable vicemariscal], le traspasó el corazón, y cayó muerto al suelo» (El vicemariscal y Carlota, pág. 259). Para García Malo el súmmum de este tipo de muertes violentas lo constituye el despeñamiento por un precipicio, tal como le sucede al marido de Rosaura, probablemente el personaje más cruel de toda la colección narrativa de nuestro autor: «Nadie se atrevia á detenerlo [el caballo que montaba el duque], y ya ciega é impetuosamente se precipitó por unos eminentes escollos haciendo mil pedazos al Duque» (Lisandro y Rosaura, pág. 96).

38 Aunque no debe ignorarse que, desde otro punto de vista, podrían también entenderse sus crecientes padecimientos como un castigo a su osadía revolucionaria.

39 Paralelamente, por medio de la decoración y del vestuario de otros intervinientes, se contribuye también a significar el cambio de ánimo operado en la plaza toledana una vez conocida la muerte de Padilla: «En el Real Alcazar de Toledo, salon magnificamente adornado» (I, 1, pág. 1); «El mismo salon enlutado» (II, pág. 32); «Nobleza, Pueblo, y Soldados, todos con gasas en los sombreros» (II, 1, pág. 32); circunstancias que potencian, además, el clima de tragedia.

40 En sentido opuesto, René Andioc había anotado en Sur la querelle du théâtre au temps de Leandro Fernández de Moratín, p. 320 —en comentario por cierto suprimido en su posterior Teatro y sociedad en el Madrid del siglo XVIII.— que «García Malo accroît la gravité de la rébellion en présentant comme un sacrilège l'utilisation des trésors des églises de Tolède à des fins militaires». 
Que si esta accion no hacia con fin recto

Por el bien de la patria, y por el culto

De su divina Ley y sus preceptos,

Me quitase la vida con asombro,

Y sirviese mi muerte de escarmiento,

Antes que profanase el Santuario ${ }^{41}$.

(I, 10, pág. 27)

Tal pasaje le vale a McClelland para reputar la pieza como ámbito donde se acoge la controversia razonada: «This tragedy also debates opposed opinions extensively, for example in arguments for and against appropriation of Church property to defray the costs of defending Toledo» ${ }^{42}$.

El confuso planteamiento —inconsciente o trabajado — de la finalidad perseguida conduce también a la reseña del Memorial literario a temblorosos vaivenes en la definición moral de la protagonista, verdadera piedra angular de la intención del dramaturgo, fuera ésta cual fuera:

A primera vista parece ser esta Tragedia poco á proposito para excitar en el espectador las dos pasiones de terror y compasion, por ser el personage principal malo, á la semejanza de la Medea: pero ademas de que en una colision de opiniones en el obrar, lo que á unos parece mal á otros parece bien, y por consiguiente segun el modo de pensar hay contrarios efectos en los corazones; hemos de mirar la accion de $\mathrm{D}^{\mathrm{a}}$ Maria de Padilla, nacida solo del sentimiento de la muerte afrentosa de su esposo por seguir un bando. En este supuesto obra agitada de aquella pasion que le parece justa, ayudado á sostener su carácter del amor á su marido: pero las mutaciones de la fortuna que padece le hacen conocer la mano del Cielo, y entrar en el conocimiento de la errada senda que llevaba, y en esto es tan heroica como antes, pues se arrepiente de sus anteriores acciones mas vuelta en sí por sus contratiempos ${ }^{43}$.

En el lado de los sublevados hay que destacar, asimismo, la figura de Matilde, esclava de María Pacheco, y a quien, como perteneciente a una más baja clase social, pretenden los nobles realistas adjudicar la responsabilidad última de la rebelión, considerándola, al paso, como un ser por entero inicuo. Y si bien

41 Es el patriotismo, cualidad como hemos visto positiva, la que empuja y cohonesta esa acción, y que poco después (I, 10, pág. 29) se reitera: «La patria asi lo exîge, y el Estado / De un Reyno, que se ve triste y opreso».

42 I. L. McClelland, Spanish drama of pathos. 1750-1808, vol. I, pág. 259.

43 Memorial literario, instructivo y curioso de la Corte de Madrid, t. XVIII, 1789, pág. 121. 
es verdad que en algún concreto episodio se manifiesta, presa de un talante revolucionario, irrespetuosa hacia un superior, caso de aquellas palabras a López:

No temo vuestras iras, ni amenazas,

Quando tengo en mi abono todo el pueblo

(I, 9, pág. 23),

no es menos cierto que lo hace impelida de un espíritu patriótico, similar al de su ama:

¿Es posible que siendo Castellano,

Esteis en vuestro error tan terco y ciego,

Que querais vér la patria destruida,

Sin que os cause dolor, ni pena el verlo?

(I, 9, pág. 22),

y que por aquella su señora experimenta un sincero cariño, así como inquebrantable lealtad y reverencia constante, cuestiones que son comprobables por los hechos (permaneciendo fiel hasta el final, en contraposición a D. Íñigo o al pueblo en general) y ratificadas por los dichos:

Eso sí, mi Señora, à vuestro lado

Me tendréis con valor hasta que muera.

(II, 11, pág. 63)

Además, a semejanza de su dueña, le es conferida la gracia de mostrarse como persona de fe, detalle importantísimo para Ignacio García Malo:

La inocencia

Abatida, ultrajada y oprimida,

Siempre encuentra socorro en la clemencia

De los divinos Cielos, pues la amparan

Contra la sinrazon y la cautela.

(II, 10, pág. 59)

Respecto al bando rival, son López y Mondéjar los que llevan el peso principal de la tragedia. El primero de ellos se nos muestra como individuo sensible, pero de índole egoísta, y sólo preocupado por los suyos. Así, lo observamos conmovido, e incluso llorando (I, 1, pág. 4 y I, 2, pág. 6) al conocer la muerte de su 
hijo; o cuando en vano procura convencer a la viuda de éste para que abjure de sus principios políticos y salve, de ese modo, la vida:

Esto vengo à rogarte por tu hijo,

Por tus pobres hermanos, por tus deudos,

Por mí, por mi hijo amado, y estas canas;

$\mathrm{Y}$ en fin por todo el Cielo te lo ruego.

(III, 3, pág. 73).

Pero en su naturaleza reside también una vena de inflexibilidad en las ideas que le hace suponerse en posesión de la verdad:

$[\ldots]$

ni à mis voces

$\mathrm{Y}$ justas advertencias se sujeta.

(II, 2, pág. 37)

¡Ah! la razon su enojo no refrena

(II, 3, pág. 39),

y de impiedad, tratándose de personas que no componen su círculo afectivo; como se echa de ver con su respuesta a la súplica que le hace Matilde para que la libere, justo en los momentos en que él está intentando propiciar la fuga, ni siquiera solicitada, de María. A la criada, por contra, le espeta esto:

No la mereces [la libertad],

Pues eres de estos daños el fomento.

Pagarás con la vida en un cadahalso

Tu infame seduccion, tu vil consejo.

(III, 11, pág. 89)

Por si fuera poco, el autor le hace incurrir además en una mentira; este suceso tiene lugar cuando, en otro diálogo anterior con la propia Matilde, asevera categórico:

No lloro yo su muerte [la de su hijo]; solo siento

Que siguiendo tus pérfidas idéas,

Manchó su sangre ilustre con sus yerros

(I, 9, pág. 23), 
pues, aunque la doméstica de María ignore la falsedad, el lector-espectador conoce aquel planto previo de López (I, 1, pág. 4), pleno de cariño paterno:

¡Ay hijo de mi vida! ¡ay hijo amado! (llora.)

En cuanto al marqués de Mondéjar, nos parece bastante significativa la misma presentación que de él se hace en la obra (II, 6, pág. 42), y que puede servirnos ya, ab initio, para darnos una idea aproximada de la «sinuosidad» de su carácter: «Doña Maria, el Gobernador D. Iñigo, y despues el Marques de Mondejar cubierto el rostro con una banda». Y poco después (II, 6, pág. 43) se insistirá en dicho procedimiento con otra acotación: «Fingiendo la voz».

Este aire de clandestinidad y ocultamiento se verá ratificado de nuevo en su persona más adelante (III, 8, pág. 80), cuando intenta, furtivo, librar de la prisión a su hermana: «sale Mondejar de capa», «Es de noche, y sin luz»; apuntamientos del dramaturgo que se ven inmediatamente corroborados por las expresiones con las que el personaje informa de su propósito:

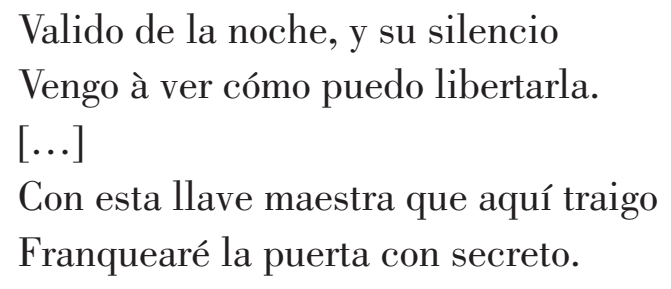

De otra parte, participa Mondéjar, junto con López, de la radical seguridad de estar situado en el «lado bueno» de la contienda:

La razón y justicia nos animan,

Y es preciso que el Cielo nos proteja

(II, 8, pág. 57),

o, por decirlo con mucha mayor claridad, en el más adecuado para su provecho; ya que, de otra forma, no sabría explicar en qué superan o son mejores ellos que los rivales. Su deficiencia argumental se pone de relieve sobremanera cuando prueba a persuadir a su hermana para que se entregue y, en vez de razones, únicamente se le ocurren intereses, o apelaciones a la veta sentimental (II, 7, pág. 46):

Ya que por mí no cedas, cede al menos

Por esta criatura amable y tierna. 
$[\ldots]$

Reflexîna que oprobrios è ignominias

Serán su mas horrenda y vil herencia

$[\ldots]$

¡Ah hermana! à compasion te mueva el llanto

De un hermano afligido que te ruega.

Por la sangre que alientas de tus padres,

Lleno de confusion y de tristeza,

Que sigas las vanderas imperiales,

E inspires en Toledo la obediencia.

Su innata disposición para mirar por la propia conveniencia está fuera de toda duda, pues su celo, repetidamente expuesto, por convertir a su hermana al credo imperial no tiene más base que la de no perder crédito él entre sus pares:

Acuerdate que tienes tus hermanos

Sirviendo al Rey, siguiendo sus vanderas.

Considera que manchas nuestra sangre

Con accion tan iniqua y tan proterva.

(II, 7, pág. 45)

Yo solo la aconsejo, Pedro López,

Que se aparte al instante de esta guerra,

Porque ha de ser su muerte la ignominia

De nuestro puro origen y nobleza.

(II, 8, pág. 48)

Miro tambien su afrenta como propia.

(III, 1, pág. 69)

Asi evitar podrás la grande afrenta,

Las injurias, infamia y vituperio

Que nos ha de causar tu horrenda pena.

(III, 9, pág. 83)

Y, junto a la filaucía, un sí es no es de inconsistencia y desmayo en sus principios; porque el rigor teórico de sus previsiones: 
Y si esta vil Ciudad se abrasa en llamas,

Como viva mi Rey, muera quien muera;

Pues aunque de mi hermana la perfidia

Turba mi corazon, y me avergüenza,

Por ser leal vasallo yo no escucho

Los gritos que me dá naturaleza

(II, 9, pág. 56),

darán al traste a las primeras de cambio:

Aunque sé de mi hermana la perfidia,

Todas sus desventuras tanto siento,

Que el corazon me oprimen, y atormentan.

Valido de la noche, y su silencio

Vengo à ver cómo puedo libertarla.

(III, 8, pág. 80)

Sobre López, Mondéjar y Sosa, el mencionado criado de Padilla, había Andioc considerado en un principio que debían «susciter l'admiration, donc emporter l'adhésion du public, parce qu'ils sont capables contrairement à la veuve de Padilla, de faire taire leurs sentiments au bénéfice de l'amour de la patrie, de la loyauté envers le monarque» ${ }^{44}$. Parecer que se vio parcialmente reformado por el mismo investigador unos años más tarde: «Este es el héroe oficial [se refiere sólo a Mondéjar] que el despotismo ilustrado propone a la admiración e imitación de los españoles: un individuo capaz de dominar sus impulsos naturales, sus sentimientos, de alienar, en una palabra, parte de su personalidad en beneficio de la patria» ${ }^{45}$.

Pero, sin embargo, creemos que, tal y como lo hemos formulado, el suegro y el hermano de María anteponen su parentesco al sentido del deber cuando tratan por todos los medios, ilegales incluidos, de salvarla; y que, por si fuera poco, trascendiendo a la mera actitud de nepotismo, un tufo de componenda, de sectarismo, de abuso de poder, en fin, inunda el universo de los próceres leales a Carlos V, en beneficio de alguna persona particular, conforme se ilustra con el más que benigno juicio de Haro, jefe de aquellas tropas, para con las delictivas maniobras de Mondéjar, las cuales absuelve al punto que las conoce (III, 12, pág. 91):

44 René Andioc, Sur la querelle du théâtre au temps de Leandro Fernández de Moratín, pág. 320.

45 Teatro y sociedad en el Madrid del siglo XVIII, págs. 292-293. 
Vos hicisteis de hermano los oficios,

Y por esto os perdono ese defecto,

Aunque obrasteis muy mal.

Para Andioc, sin embargo, estos comportamientos se ven excusados por razones tan naturales como son las de procurar la salvaguarda de un ser querido, por más que hubiera luchado en un bando contrario ${ }^{46}$, o por más que tales acciones resultaran muestra de un claro favoritismo; pero esta explicación, que en otro tipo de obra hubiera pasado por bien plausible, se nos hace más difícil de aceptar en esta que gira en torno a una serie de decisiones del rey o de su entorno, cuestionadas precisamente por arbitrarias y partidistas. Es decir, aquí los miembros están haciendo lo mismo que la cabeza, y todos en detrimento de lo que parece justo.

Y hasta D. Íñigo, el gobernador de tan volubles fundamentos, a quien ningún lazo de familia ata a María, se anima, una vez pasado a la orilla imperial, y como si fuera consustancial a ella, a infringir la ley, tratando de cooperar con López en el plan de fuga de María: «A quanto propongais estoy resuelto» (III, 11, pág. 88).

Constituye, por otro lado, este versátil sujeto, por encima de una aparentemente superflua intromisión en la obra, elemento de la más grande importancia, por cuanto con él palmariamente se demuestra que no fue privativo sólo del vulgo el desertar en la desgracia, construyéndose a la vez, de ese modo, un atenuante más en la responsabilidad del pueblo por la muerte de la protagonista.

Ya se cuida el escritor de hacer bien abrupta la transición entre una primera y otra segunda obediencia, pues si en un principio pomposamente Íñigo proclama:

La Ciudad à mi cargo se halla toda:

Me toca defenderla con esfuerzo,

Y derramar la sangre que me alienta

Por mí mismo, por ella, por mi empleo

(I, 7, pág. 19),

o promete a la Pacheco:

46 «La tragedia no es ningún tratado abstracto o teórico de política, sino, cuando más, la teatralización de un conflicto político por medio de unos personajes que la sacrosanta verosimilitud invitaba a considerar homólogos de los espectadores, esto es, dotados de sentimientos y humanidad; de ahí resulta que la rigidez de las propias convicciones pueda sufrir, sin que de deslealtad se trate, alguna "flaqueza" o, como dice Haro un “defecto grave"» (René ANDioc, «Doña María Pacheco, ¿mensaje preliberal?», en Guillermo Carnero, Ignacio Javier López y Enrique Rubio [coords.]: Ideas en sus paisajes. Homenaje al profesor Russell P. Sebold, Alicante, Universidad de Alicante, 1999, págs. 71-84, pág. 76. Dicho artículo es recogido por el mismo Andioc, con alguna modificación, en su libro Del siglo XVIII al XIX. Estudios histórico-literarios, Zaragoza, Prensas Universitarias de Zaragoza, 2005, págs. 417-439, obrando las palabras aquí transcritas a la página 427). 
A vuestro lado un rayo seré siempre,

Pues mi valor aníma vuestro zelo

(I, 10, pág. 31),

no perderá, luego, tiempo en entregarse al enemigo:

$[\ldots]$

yo viendome sorpreso, à sus propuestas

Me he rendido al instante ${ }^{47}$

(II, 11, pág. 62);

llegando, no sabemos si en su simplicidad o en su bajeza, a pasmarse del cambio de criterios de la plebe ${ }^{48}$; inversión de ideas de la que él es, como queda apuntado, precursor y, no bastante, en buena medida el culpable. Esta última presunción se alcanza conectando la derrota militar de las huestes que regía con aquellas palabras de la heroína con las que, ante su imposibilidad por hallarse herida, delegaba en Íñigo las providencias a adoptar, y que, a juzgar por el resultado final, ha de imaginarse que éste no supo cumplir:

Esta empresa

Ha intimidado mucho à nuestra tropa,

Y si el Gobernador no vá, y la alienta,

Abatido el orgullo de la plebe,

Grandes calamidades nos esperan,

Corre al punto, y prevenle de mi parte,

Que reuna la tropa yá dispersa,

Que pinte à todo el pueblo nuestro estado,

Nuestro inminente riesgo y contingencia;

Que repare los daños de los muros,

Las ruinas de las torres y las puertas,

Y hallará el enemigo de este modo

En un súbito asalto resistencia.

(D. ${ }^{a}$ María a Matilde, II, 4, pág. 40)

47 No sólo eso, sino que se nos constata una defección en toda regla hija de la cobardía (III, 5, pág. 77), según los versos que antes ya reprodujimos: «Aturdido me tiene este suceso; / Aunque yo del peligro estoi ya libre, / Porque presté à mi Rey el juramento / De seguir sus vanderas, y partido, / Y dexar à los vandos comuneros».

48 En un diálogo con Pedro López, acerca de la pretensión del pueblo de acabar con la viuda de Padilla, se atreverá a decir: «iQue ruinas! ¡Qué alborotos! ¿Qué mudanzas!» (III, 4, pág. 76). 
Y es la voz del mismo gobernador quien revela su adelanto en rendirse respecto al grueso de los habitantes de Toledo, puesto que, después de comunicar su cambio de bando a la dirigente comunera, anuncia: «Casi toda la plebe ya vacíla» (II, 11, pág. 63) ${ }^{49}$.

Anota Andioc para esta tragedia, así como para la Raquel, que

[...] se trata en ambos casos de minimizar la falta cometida por unos nobles, en la medida en que la solidaridad de clase es más poderosa que las discrepancias momentáneas, como lo era la realidad contemporánea. El verdadero antagonista de los nobles y del rey lo constituyen en efecto las masas populares que no tienen derecho a sacudir el yugo de la explotación monárquico señorial ${ }^{50}$.

Y en línea con este comentario asevera:

Ese pueblo ingrato no vacila en matar, en Doña María Pacheco, a la que defendía. No sólo queda entonces desacreditado moralmente, sino que también y sobre todo se evita por lo mismo la embarazosa necesidad de hacer ejecutar a un noble por la justicia real, como ocurrió en la guerra de las Comunidades ${ }^{51}$.

Sobre este último particular, que no nos convence, hay que significar que la tragedia precisamente se inicia dando cuenta de la muerte de Padilla; esto es, de la ejecución de un noble por la justicia real.

Sostenemos, al revés, que la sustracción del proceso ordinario y esperado, por el que habría de darse muerte a la protagonista en un cadalso, constituye una más de las incógnitas de la tragedia. Especialmente, si se entronca con el dictamen que el autor coloca en el «Prólogo» acerca de las repúblicas, «en las que (siendo bien ordenadas) se executan en público los castigos para escarmiento de los malos» (h. s. n.).

¿Eso equivale a decir que García Malo pensaba que el de Carlos V era un país desarreglado? No lo sabemos. Pero es lo cierto que no pudo aplicarse a la rebelde la pena legalmente prevista por culpa de un ejército real que no sólo se vio incapaz de aplacar los alborotos en la ciudad tomada, sino que ni tan si-

49 De ahí que hayamos de disentir del siguiente comentario de Guillermo Carnero: «D. Íñigo secunda desde el comienzo las actitudes de $\mathrm{D}^{\mathrm{a}}$ María y asume su oposición a los argumentos de D. Pedro (I, 3), pero luego se arrepiente al constatar la inconstancia y vileza del pueblo, que reclama la muerte de $\mathrm{D}^{\mathrm{a}}$ María ante el fracaso de la rebelión, y jura fidelidad al rey (III, 5)» (Ignacio García MaLo, Doña María Pacheco, mujer de Padilla, ed. de Guillermo Carnero, pág. 31).

50 René Andioc, Teatro y sociedad en el Madrid del siglo XVIII, pág. 294 (reproducción casi literal del fragmento de Sur la querelle du théâtre au temps de Leandro Fernández de Moratín, pág. 324).

51 René Andioc, Teatro y sociedad en el Madrid del siglo XVIII, pág. 296. 
quiera supo garantizar la disciplina entre aquellos de los suyos que, por asuntos familiares, burlaron las reglas; coyuntura que justamente se erige en la causa que provoca y desencadena el asesinato de María, la cual anda deambulando por la calle cuando debería estar presa ${ }^{52}$.

Nuevo factor de desconcierto, respecto de una presuntamente nítida tesis política de la pieza, lo componen las réplicas automáticas que se suscitan en torno a la cuestión de fondo, sin que, en definitiva, se vean superados los argumentos de unos por los de los otros. De ahí, que el juicio de López (II, 8, pág. 49):

No fue la libertad, ni el patriotismo

El que encendió la llama de esta guerra,

Fue solo el interés, y la avaricia,

reciba el inmediato mentís de María Pacheco (II, 8, págs. 49-50):

La envidia, y la avaricia en vuestros pechos

Es la que predomina, y la que reyna;

Pues pensais que sirviendo al Rey leales

Adquirireis honores, y riquezas;

y que los reproches de Mondéjar (II, 8, pág. 50) por la caótica situación creada:

La república gime en la pobreza.

Todos son desacatos, muertes, robos,

Maldades, atentados, è insolencias,

sean contundentemente neutralizados por las razones que explana su colactánea (II, 8, págs. 50-51):

Los estragos, y males que publicas provienen del rigor, y prepotencia.

52 Distinta es, no obstante, la explicación aportada por quien, enmascarado tras las siglas J. O. D. T. (ignoramos si auténticas o licenciosamente buscadas por malsonantes), escribe en el Diario de Madrid del 13 de noviembre de 1789 la «Carta sobre el mal gusto del Vulgo en los Dramas disparatados, y elogio de los bien escritos», donde se afirma lo siguiente: «El venirle el castigo de un modo extraordinario, ó como disposicion del Cielo, hace mas detestables [sic] el error, y es un fin mas tragico y moral que el morir en un suplicio en castigo de sus delitos. Quien sepa distinguir la tragedia de la comedia, conocerá que su conclusion debe ser muy diferente. Veanse los buenos modelos, y se verá que la conclusion de la Pacheco es como debe ser» (probablemente la primera noticia escrita acerca de este artículo corresponda a Ramón del Toro y Durán en su reseñado Catálogo..., págs. 38-39, a través de una nota al pie). 
Si ésta no hubiera opreso à la Castilla,

Si no hubiera extrahido sus riquezas,

Si hubiera administrado la justicia,

Y guardado sus justas preeminencias,

¿Se hubieran suscitado las discordias? ${ }^{53}$

La reversibilidad en las proposiciones conoce su cénit en unas palabras de López (II, 9, pág. 55):

Que ni aun la misma sangre nos obliga

A cometer maldades, ni vilezas,

Sino que preferimos ser leales

A costa de quien tiene sangre nuestra,

las cuales, sin quitar ni corregir coma ni tilde, podrían perfectamente haber sido pronunciadas por su hija política, a quien la descripción que ni de molde le venía después de haber pospuesto los lazos familiares a la fidelidad en un proyecto.

Dialéctica ésta de pugna verbal que, de otra parte, Benítez Claros juzga fenómeno típico de la tragedia de la época, en mengua de la psicología del personaje: «Por eso, sin duda, suele ser tan débil el trazado de los caracteres, porque la preocupación recae por completo en el planteo de una buena lucha ideológica, concebida al margen de la criatura, que va a ser luego la simple portadora del suceso, no la potente autora de él» ${ }^{54}$.

53 Aunque hemos hablado del pie de igualdad a la hora de expresarse las respectivas y tan contrarias posiciones, no se puede negar que los cuatro últimos versos consignados ayudan a pensar que únicamente muy sólidos y fundamentados motivos podían empujar a un enfrentamiento armado, recurso extremo que sugiere la esterilidad de otras vías presumiblemente intentadas. Las quejas — motivo de la guerra — que en la realidad del siglo XVI se habían levantado en Castilla no debían de ir tan desprovistas de razón, cuando en la núm. XXXIV de las Epístolas familiares y escogidas («Razonamiento hecho en Villabrájima a los caballeros de la junta»), escritas por Antonio de Guevara — precisamente una de las obras que Guillermo Carnero (edición de la Voz de la naturaleza, pág. 69) señala como inspiradora del asunto que en su tragedia trae García Malo-, podemos leer esto: «Y porque no parezca que vuestro celo [el de los comuneros] ha sido en vano, que los gobernadores no desean el bien del reino, quiéroos agora aquí mostrar lo que ellos por el reino quieren hacer, y por otra parte S. M. merced os hacer, que son las cosas siguientes». Y realiza inmediatamente después una larga enumeración de concesiones; destacando entre ellas la de que, en ausencia del rey, no ha de ponerse de gobernador en Castilla a ningún extranjero, o aquellas otras que miran a que todas las dignidades, tenencias, encomiendas, y oficios del reino y Corte se darán a españoles (vid. op. cit., Barcelona, Biblioteca Clásica Española, 1886, págs. 179-181).

54 Rafael Benítez Claros, «Notas a la tragedia neoclásica española», en Homenaje a Fritz Krüger, t. I, Mendoza, 1952, págs. 431-464, pág. 462. Teoría que repite en Visión de la Literatura española, Madrid, Rialp, 1963, pág. 198. 
Hay una materia, sin embargo, que, traída a colación por los seguidores de la Corona, no encuentra respuesta por la parte contraria. Se trata del famoso origen divino del poder real. Curiosamente, la presentación del tema no se nos figura la más apropiada para una contestación, puesto que dicho punto es sucedido y difuminado por una serie de improperios a la tropa comunera en las dos oportunidades en que aflora; y ese paso de lo general a lo particular o personal acaba por desatar la furia, antes que el contraargumento, en María, destinataria de esas manifestaciones.

En uno de los casos es Mondéjar, personaje ya por sí mismo desacreditado, el que indirectamente aborda el asunto:

Contra el Cetro oponerse nadie debe:

Sacrílega es la accion, y à ley opuesta

(II, 8, pág. 51),

aunque, acto seguido, pasa a despacharse con un largo parlamento (II, 8, págs. 51-52) preñado de insultos a los insurrectos.

Anteriormente había sido López el que había mencionado el asunto, si bien en un pronunciamiento en el que parece dejarse entrever la existencia de algunos supuestos «discretos» —entre los que no se encontraría, naturalmente, el que nos ocupa- en donde pudiera estar legitimado el súbdito para alzarse contra su señor, a pesar de la teórica procedencia de la autoridad de éste (I, 10, pág. 30):

¿Con qué razon el Reyno perturbasteis, Y quereis de Toledo haceros dueños? ¿Qué divina, ni humana ley permite, Que el vasallo por fines indiscretos Alborotos levante, y haga guerra A un señor natural que le dá el Cielo?;

pero la palabra no pasa después de ese momento a su oponente dialéctico para que alegue sobre tal declaración, sino que, prosiguiendo en su uso, muda López de tercio para denostar al enemigo:

¿El Estado y la Patria se defiende Quemando sus Ciudades y sus pueblos,

Cometiendo atentados y maldades, Robando sus Iglesias y sus Templos?

(I, 10, pág. 30) 
Resulta, en fin, que el manejo de la presunta derivación divina del poder no se efectúa de la manera terminante y concluyente que pudiera esperarse del mismo autor que el texto del «Discurso preliminar» a la Ilíada, que más atrás quedó reflejado ${ }^{55}$.

Ello no debe extrañarnos, empero, porque a aquella tajante formalización seguía, como suavizándola, las exigencias que ha de observar un monarca:

Tambien se hallan explicadas en diferentes partes [de la Ilíada] las qualidades de un buen Príncipe, entre ellas el amor á la piedad, rectitud y justicia, que son los más seguros medios de hacer felices los Estados, de vér reynar la abundancia, la fecundidad, la paz y buen orden, efectos de un gobierno equitativo y justo: la prudencia y sabiduría, esa virtud tan necesaria á los Príncipes [...], la vigilancia en cuidar su rebaño como Pastor del Pueblo, que asi le llama Homero, cuya qualidad le proporciona el interno é inalterable placer de hacer felices á los que viven báxo su imperio ${ }^{56}$.

Las dudas, en cuanto a una hipotética pretensión del dramaturgo por salvaguardar al rey de todo punto de mira crítico y aupar su figura por encima de cualquier humana disputa, tampoco quedan disipadas en las intervenciones últimas de la protagonista. Y ello a pesar de la aparente claridad con que se retracta:

Por tanto, arrepentida de mis culpas,

Hago solemne y firme juramento

De lealtad al Rey; y à todos pido

Que obedezcan sus leyes y preceptos.

¡Oh quién vivir pudiera, para darle

De mi obediencia ciega algun exemplo!

$[\ldots]$

Pero yá, hijo querido, que asi muero,

Procura tú lavar tanta ignominia,

Derramando tu sangre con denuedo

En defensa del Rey. Nunca te opongas

Al Rey, à sus Ministros, ni decretos,

Aunque juzgues te asisten mil razones;

55 Tampoco ha lugar a rebatirse, por tratarse de parlamento pronunciado a solas por López, aquella su personal observación: «Bendita sea siempre la obediencia, / La lealtad y amor que usar debemos / (Porque Dios nos lo manda) à los Monarcas» (III, 2, pág. 71).

56 Ignacio García MALO, «Discurso preliminar», en la Ilíada de Homero..., págs. LXXXV-LXXXVI. 
Porque es muy imposible penetremos

Los arcanos de aquel que nos gobierna,

Como que los inspira el justo Cielo

(III, 12, pág. 93),

pues su rectificación es contemplada como hija de un arrebato repentino, fruto de la decepción y de la ira hacia un pueblo que paga los sacrificios por ella arrostrados con la herida mortal que le inflige, y no del análisis razonado y objetivo, camino lógico para el convencimiento. Esta cuestión personal no se verá reforzada por ningún nuevo argumento con que pudiera ser contrarrestado o invalidado lo sostenido hasta el momento por la cabecilla de los amotinados; debiendo tenerse en cuenta, además, como elemento diferenciador entre tan brusco tránsito en el pensar la sustancial modificación de su condición física - y paralelamente psíquica, quizá - que muda de la plenitud a la debilidad extrema y a la agonía ${ }^{57}$.

Aparte de esto, hay que valorar también el hecho de que no es la primera vez que María torna radicalmente de postura y que parece persuadida por el rival. En efecto, en determinada conversación con su hermano (III, 9, pág. 83) pasa de rechazar la huida ofertada a aceptarla de inmediato, sin pasos intermedios:

Me convenzo.

Desde luego estoy pronta à retirarme.

Dime cómo ha de ser,

con el premeditado empeño de volver por sus fueros (III, 10, págs. 84-85):

Aunque à las persuasiones de mi hermano,

Sin réplica ninguna condesciendo,

No es por temor alguno, ni vileza.

Mi intencion se dirige à buscar medios

Para volver triunfante à la venganza.

Por lo mismo ahora, en su trance final, puede la de Padilla estar diciendo una cosa para alcanzar otra; esto es, para tratar de paliar las repercusiones ne-

57 Para Reyes Narciso este cambio repentino en la actitud de María Pacheco «resta verosimilitud a la tragedia», alegando que «se justifica por el fuerte componente didáctico» (Reyes Narciso García-Plata, «Nueva aproximación al estudio del recurso del contraste en la tragedia neoclásica: los personajes», Anuario de Estudios Filológicos, vol. XXV (2002), págs. 327-343, pág. 340). 
gativas de su anterior conducta — y la de su esposo— en el futuro de su hijo, el cual va a quedar — si bien en manos familiares_ dentro del ámbito imperial. En su cabeza, al menos, está presente esa situación:

Mas yá siento que el ánimo fallece;

Y el único dolor que yo padezco

Es morir con la tacha de revelde,

Y dexar à este niño en años tiernos.

Quando seas adulto, hijo del alma,

Y te digan la muerte que tuvieron

Tus infelices padres, ¡qué vergüenza

Cubrirá de rubor tu rostro bello! ${ }^{58}$

(III, 12, pág. 93),

y de ahí la exhortación (III, 12, pág. 93), más arriba transcrita, que le hace ante terceros para que repare con la suya la actuación de sus progenitores.

Asimismo, habría resultado más rotundo y efectivo el arrepentimiento de la heroína de haberse dado por sentado en algún momento su incompatibilidad con una forma monárquica de gobierno; circunstancia que no se da ni por asomo. Antes bien, la tendencia es a explicar la revuelta como un acto que no choca frontalmente con la persona o la figura del rey. Por eso, ya desde temprano (I, 3, págs. 11-12), María elucida:

El Rey ausente ignora lo que pasa,

No sabe las miserias de su Reyno:

Los Nacionales viven agoviados;

Los Extrangeros tienen los empleos:

Ellos con dura mano nos afligen,

Y exhaustos de riquezas ya los pueblos

Están aniquilados bajo el yugo

De un infame despótico manejo.

E incluso la propia comunera pone a todos como ejemplo a imitar el de una soberana, abuela, por cierto, de Carlos V:

58 No deja de extrañar tampoco que en el mismo parlamento, unas frases antes (pág. 92), hubiera proclamado esto: «Porque à los Soberanos, como à Dioses / Es preciso que todos veneremos». ¿Puede alguien imaginar un plural («dioses») más a despropósito para encontrar un sentido real y concreto en la España del XVIII (menos aún en la del XVI, donde se encuadra la acción) a esa recomendación de «venerar»? 
Seguidme sin temor, con arrogancia,

Juzgando que yo soy otra Isabela;

Pues si ella entró en Granada con de nuedo,

No temiendo del Moro la potencia,

Yo ofrezco defender hoy à Toledo.

(II, 2, pág. 34)

Pero la ausencia de inquina hacia la Corona no impide que del contenido de la obra —en línea con otras neoclásicas ${ }^{59}$ — no se desprenda alguna amonestación hacia la actitud regia, referida por supuesto al contexto histórico en que se enmarca, no al coetáneo de la composición. Paradójicamente, al contrario, aquello que pudiera contemplarse censurable en el proceder del emperador Carlos repercute, ahora, en una valoración positiva de su homónimo Carlos III, que, en condiciones susceptibles de recordar a las fabuladas, cediendo, evitó una guerra abierta. Dejemos por un instante que Herr nos refresque la memoria acerca de aquel panorama: «Cuando Carlos llegó de Italia en 1759, sus súbditos profesaban poca simpatía a este extraño rodeado de ministros igualmente extranjeros. En 1776, los motines mostraron lo poco que aún les agradaba su gobierno. El rey no olvidó la lección; se españolizó poco a poco y buscó sus consejeros entre los españoles» ${ }^{60}$.

Por eso nos parece acertadísimo, en este concreto punto, el juicio de Mendoza Fillola cuando dice que «doña María de Pacheco no cuestiona o polemiza la persona de Carlos V, sino la política de sus ministros y ejército extranjero, en lo que se pone particular cuidado por parte del autor; aunque, sin embargo,

59 Hablando Glendinning del Don Sancho García (1771), anota: «En esta tragedia de Cadalso, así como en las de Moratín [Nicolás] y Montiano, el interés en torno a los deberes de la nobleza y su derecho a criticar al rey constituyen un elemento de gran importancia. El derecho que asiste a un noble para oponerse al soberano en una acción que cree que es mala o injusta se encuentra progresivamente afirmado (mediante el personaje Alek), y los deberes de la nobleza se subrayan, por otra parte, en un largo parlamento de don Gonzalo, el educador de Sancho García» (Nigel GLEndinning, Historia de la literatura española, El siglo XVIII, Barcelona, Ariel, ed. aumentada y puesta al día, 1987, pá. 184). Y poco después (págs. 185-186) añade: «Raquel va mucho más lejos que Don Sancho García o que Lucrecia en la invitación que hace a los nobles para formular su oposición frente a la conducta seguida por un rey tirano».

60 Richard Herr, España y la revolución del siglo XVIII, Madrid, Aguilar, 1975 (1. a ed. 1964), pág. 192. Salvada la alusión personal al monarca reinante, podía el autor esperar excitar «en la Tragedia, el Terror, y la Compassion, para que los Reyes, y los Poderosos moderen, y corrijan con este medio sus vicios, y Passiones violentas: porque movidos à misericordia, y lastima por la representacion de casos atroces, y lastimosos, es fuerza, que templen en parte la Crueldad, la Ira, la Ambicion; y se inclinen à las virtudes opuestas à tales vicios, y que el temor, y horror concebidos en el Theatro los haga mas cuerdos, y menos desvanecidos en la prospera fortuna; si mas sufridos y constantes en la adversa» (Ignacio de LuzÁn Claramunt de Suelves y Gurrea [Egidio Menalipo], La Poética, o reglas de la poesía en general, y de sus principales especies, Zaragoza, Francisco Revilla, 1737, pág. 351). 
demuestra implícitamente la gravedad de tal conducta por el enfrentamiento civil que provocó» ${ }^{61}$. Aunque, al revés que el propio Mendoza Fillola ${ }^{62}$, creemos, por las razones más atrás expuestas, que en modo alguno resultaba incompatible conjugar el rechazo a la rebelión armada con la crítica a una situación previa, presumiblemente injusta, que hizo brotar la chispa del conflicto.

Quizá, para un mejor entendimiento y comprensión de la, para nosotros, intrincada significación política de la obra, no debamos pasar por alto la constante recurrencia a dos imágenes: «el fuego» y «la oscuridad».

Por lo que hace a la primera de ellas (manejada por los personajes de ambos bandos sin distinción), se hace obsesiva su cualidad de devastación, siempre presente:

Quemando sus Ciudades y sus pueblos ${ }^{63}$.

A semejanza del fuego, el valor simbólico de la oscuridad remite también a mundos y experiencias del todo infelices:

Tu sombra ensangrentada en todas partes

Verán mis ojos de pesares llenos ${ }^{64}$.

Y, a la inversa, la claridad de lo blanco sugiere aspectos positivos, tales como la limpieza de intenciones y altura de miras:

Yá es tiempo que empuñando el blanco acero,

Armados de valor y de destreza,

61 Antonio Mendoza Fillola, «Aspectos de la tragedia neoclásica española», pág. 387. Respecto de este punto, Fernández Cabezón señala lo siguiente: «Quintana, al igual que su amigo Ignacio García Malo en la controvertida tragedia Doña María Pacheco, mujer de Padilla (1788), se suma a la teoría oficialista, es decir, salva al emperador e inculpa a los ministros flamencos» (Rosalía Fernández Cabezón, «Motivos temáticos en las Poesías patrióticas [1808] de Quintana», en Elena de Lorenzo Álvarez [coord.], La época de Carlos IV (1788-1808). Actas del IV Congreso Internacional de la Sociedad Española de Estudios del Siglo XVIII, Gijón, Instituto Feijoo de Estudios del Siglo XVIII - Sociedad Española de Estudios del Siglo XVIII - Sociedad Estatal de Conmemoraciones Culturales - Ediciones Trea, 2009, págs. 497508, págs. 500-501).

62 «Bien podría considerarse esta obra, además de ejemplar defensa de los valores oficiales en las postrimerías del reinado de Carlos III, como conjuro por su simbolismo, contra las posibles sublevaciones populares que se pudieran intuir en ese año de 1788» (Antonio Mendoza Fillola, «El compromiso colonial y el despotismo en la tragedia neoclásica», en Coloquio Internacional sobre el Teatro Español del Siglo XVIII, Bolonia, 15-18 de octubre de 1985, Abano Terme, Piovan Editore, 1988, págs. 267-287, pág. 281).

63 I, 10, pág. 30); parecidamente: II, 1, pág. 34 ; II, 8, pág. 51; II, 9, pág. 56_II, 10, pág. 58; II, 10 , pág. 60; II, 12, pág. 65.

64 I, 1, págs. 4-5; también I, 3, pág. 15; III, 10, pág. 86; III, 12, pág. 91. 
Contra el poder de tantos enemigos

La Ciudad de Toledo se defienda.

(II, 1, pág. 32)

No obstante, la existencia de estos solos ejemplos no habría bastado para fijar nuestra atención en ellos. La razón por la que parece conveniente que nos detengamos en el estudio de las expresiones que significan ausencia de luz deviene, además de por su frecuencia, de la importancia respecto a las posibles repercusiones de los términos del mismo entorno léxico (utilizados, bien como verbo, bien como sustantivo o adjetivo) que más directamente designan la privación total de la visión, es decir, la ceguera:

$[\ldots]$ todos ciegos

De cólera, y enojo.

(Íñigo, I, 3, pág. 13)

Ah qué furor te ciega hija imprudente Que no ves los peligros ni los riesgos.

(López, I, 3, pág. 13)

$[\ldots]$

vuestro error tan terco y ciego.

(Matilde, I, 9, pág. 22)

Un indigno furor à todos ciega.

(López, II, 2, pág. 36)

Para que esta Ciudad alborotada

Conozca los errores que la ciegan.

(López, II, 3, pág. 39)

Tus enojos te ciegan.

(López, II, 8, pág. 49)

Qué horror causa mirar estos estragos,

Y mas el verte à ti furiosa, y ciega.

(Mondéjar, II, 8, pág. 52)

Tal es la furia insana que la ciega.

(López, II, 9, pág. 53) 
¿A dónde vais guiada de la ciega

E indiscreta pasion que os predomina?

(Haro, II, 12, pág. 64)

¿Quién hubiera creido que este Pueblo,

Que amaba à esta muger tan ciegamente,

Tanto la aborreciera en un momento?

(Íñigo, III, 5, pág. 77)

Y el salvarla imposible lo contemplo,

Si aun permanece ciega, y obstinada.

(Haro, III, 7, pág. 79)

[...] viene ayrada

Y cegada de cólera y despecho

A dár la muerte à vuestra triste hija.

(Íñigo, III, 11, pág. 88).

Como fácilmente puede comprobarse a la vista de las nada menos que doce ocasiones en que surgen dichos términos, con el negativo sentido, siempre y sin excepción, de señalar una conducta irreflexiva, la utilización de los mismos se extiende a todos los personajes que tienen una mínima relevancia en el drama. A todos, salvo a uno, el fundamental: D. ${ }^{a}$ María Pacheco.

Por otro lado, la connotación de «ceguera», y su familia léxica, como elemento irracional e irreflexivo, queda acentuada con la exposición del propio autor en la «Nota» que precede a la tragedia (que la antecede físicamente en la edición, pero que por lógica seguramente fue escrita después), y donde García Malo dice sustituir (y por tanto de alguna forma equiparar) «los agüeros falsos de la esclava» por una razón distinta, la de pintar a la sirvienta como «confidente de Doña María, y haciendo que ésta siga, por la mucha estimación y concepto en que la tenia, ciegamente todos sus consejos» (h. s. n., la cursiva es nuestra).

Por eso, tal parece, después de conocer la alta frecuencia en el manejo de esa significación de «ceguera», el amplio espectro de individuos que la invocan, así como las connotaciones a las que siempre apunta, que la misma se constituye en la síntesis que Malo concibe para el ambiente propio de los conflictos bélicos; y que con ella se quiera recalcar el concepto de que los males derivados de la guerra no esquivan ni perdonan a nadie, sean de uno u otro bando.

Y si bien la protagonista no tuvo participación en ninguna de las doce oportunidades anteriores en que salió a relucir aquella idea, es justamente al final de 
la obra, en el último parlamento de María, cuando el contenido de este tipo de vocablos está ya perfectamente definido por el uso, después de haber mantenido continuamente esa dirección descrita de «declarar insensatez» o, más exactamente, «irracionalidad», fruto de la ofuscación, de la enajenación momentánea, pero nunca de la lógica, es entonces, decimos, cuando la Pacheco exclama:

¡Oh quien vivir pudiera, para darle [al rey]

De mi obediencia ciega algun exemplo!

(III, 12, pág. 93).

Cabría preguntarse ahora si, con la enunciación de este propósito, la heroína simplemente estaba dando a entender lo que sus interlocutores, del bando imperial, creían tratarse de una retractación; si, en cambio, pretendía insinuar, acaso, que aquel rey no se merecía sino una acatamiento rutinario, una esclavitud exenta de cualquier otro valor positivo que pudiera alentar el vasallo hacia su monarca; o que, en fin, y desde otro ángulo, que sólo como producto de un acto inconsciente podría ella renunciar a sus ideales.

Por todo lo cual, una vez más, se nos hace imposible desentrañar el verdadero pensamiento del autor en estas cuestiones.

\section{Respuesta del público a la tragedia}

No podemos dejar de dedicar unas cuantas líneas a tratar de desmontar otro de los argumentos esgrimidos para tildar la pieza de defensora del totalitarismo monárquico, cual fue - en la idea enunciada ya en 1792 por el abate Marchena- el de atribuir el fracaso de la representación al vilipendio de la protagonista por parte del autor, y la consiguiente reacción en contra del público hacia ese retrato presuntamente hostil de doña María Pacheco y del pueblo que la seguía.

Ha de significarse, al efecto, que Doña María Pacheco gozó del favor de la representación los días 7 y 8 de septiembre de 1789, en el Teatro de la Cruz, por la Compañía de Martínez ${ }^{65}$, después de que su autor percibiera por ello 900

65 En ambas fechas inserta el Diario de Madrid idéntico párrafo para su anuncio: «En el de la calle de la cruz, por la Compañia de Martinez, la tragedia intitulada: la Muger de Padilla, Doña Maria de Pacheco, en tres Actos, nueva, con una tonadilla que cantan las Sra. Nicolasa Palomera, Antonia Orozco, Navarro, y Camas, nuevas, y por fin de fiesta el saynete intitulado los Majos Vencidos». Por tal motivo ignoramos la razón de que Guillermo Carnero, en la ya citada edición que realiza de Voz de la naturaleza, consigne erróneamente, en la página 53, el día 5 de septiembre como el del inicio de su puesta en escena. Posteriormente suprimirá este dato en Estudios sobre narrativa y otros temas dieciochescos (Salamanca, Ediciones Universidad de Sala- 
reales de vellón que le pagó Juan Lavi, según documento extendido por García Malo a Juan Gordón, administrador del propio de comedias de Madrid ${ }^{66}$. Y se recaudaron a su costa un total de 10.099 reales, según da cuenta el Diario de Madrid del 9 de septiembre de ese 1789: «La entrada de antes de anoche fué de 4810, y la de ayer tarde de 5289» (más alta, por caer en día de fiesta).

Al tercer día, sin embargo, fue retirada del cartel y sustituida por El día de campo, también a cargo de la Compañía de Martínez. Tan temprana caída, como ya hemos apuntado, se ha querido ver por algún autor como rechazo del pueblo llano por sentirse allí atacado.

De todas formas, la calidad del drama es reconocida en la mencionada reseña del Memorial literario (tomo XVIII, 1789, pág. 122): «[...] tiene buena trama, facil série, y solucion no esperada, pero verosimil, bien sostenidos los caractéres, y animadas las pasiones». Es igualmente valorada de forma positiva por Forner:

La Tragedia Doña María Pacheco, escrita por un joven, que en su corta edad ha dado pruebas de la mejor disposicion para la Poesía heroyca, es una pieza bastante arreglada al arte, de verso noble, vigoroso y fluido, y sería mucho mejor si el hecho historico en que la funda, pudiese hacer amable la Protagonista como un Caton en Uticá; pero la delicadeza del asunto, y la obligacion en todo Dramático de no poner á vista del público acciones de mal exemplo, antes bien escarmientos de personas altas, capaces de distraer á los hombres de las acciones perversas, se conoce fueron causa de que el Autor no pudiese hacer ostentacion de la viveza y fuego de su imaginacion, y que se limitase á sostener la trama con la fuerza de un diálogo natural y sencillo ${ }^{67}$.

manca - Prensas Universitarias de Zaragoza, 2009), donde en el capítulo titulado «Sensibilidad y casuística moral en Ignacio García Malo» (págs. 185-282), manifiesta que reproduce y actualiza el estudio preliminar a su edición de García Malo de 1995.

66 «Manuel Gordon.- Recivi de Dn. Juan Lavi novecientos rs. vn. por la gratificacion dela Tragedia intitulada D ${ }^{a}$ Maria Pacheco, muger de Dn. Juan Padilla que se representa por la compañia de Manuel Martinez, y para que conste lo firmo en Madrid a 8 de setiembre de 1789».- Firmado y rubricado (BNM, ms. 14.0163/89-266). Esta cantidad entregada por Lavi había sido ya registrada por Jerónimo Herrera Navarro en su Catálogo de autores teatrales del siglo XVIII, Madrid, Fundación Universitaria Española, 1993, pág. 207, y en la página 208 se señala el lugar, que acabamos de consignar, donde se halla guardado dicho documento. En otro de sus estudios, el propio Herrera Navarro, citando a Doña María Pacheco entre las comedias de verano, anota lo siguiente a propósito de los precios: «Desde 1776 hasta fin de siglo, se acostumbra pagar por una comedia representada en verano 900 rs. fuera original o traducida, de dos o tres actos, de más o menos aparato teatral. Sólo tienen en común que se representaron en ese período del año» (Jerónimo Herrera Navarro, «Precios de piezas teatrales en el siglo XVIII. [Hacia los derechos de autor]», Revista de Literatura, t. LVIII, núm. 115 (enero-junio de 1996), págs. 47-82, pág. 72).

67 «Discurso imparcial y verdadero sobre el estado actual del teatro español», La Espigadera, núm. 1 (1790), págs. 1-27, págs. 19-20. Este fragmento lo reproduce Ada M. CoE en su Catálogo bibliográfico y 
Es decir, García Malo, por razones ajenas, hubo de refrenar la energía de su arte, que implícitamente se le concede.

Pero, como la conformidad de juicios parecía avenirse mal con el siglo, no todo había de quedarse en parabienes. De esta suerte, en el Diario de las Musas de 14 de diciembre de 1790 , leemos:

Daré un abanico de Filipinas al que me diga, por qué el Memorial Literario (y eso que en materia de Teatros no se la perdona á Meco) se ha dexado en el tintero la critica de la tragedia intitulada, Numancia Destruida, quando hay en ella tantas bellezas que alabar, y tantos defectos que reprender, y gasta dos parrafos en elogiar la miserable y silvada tragedia llamada la Pacheco. Si me sacan de esta duda, añadiré al abanico un par de dulces de la calle de la lechuga ${ }^{68}$.

Los pitos que se mencionan debieron producirse, en todo caso, una vez acabada la función si atendemos a la información del ya indicado J. O. D. T. que, precisamente, sobre el particular puntualiza: «He visto representar varias Comedias pocos dias hà en el Coliseo de la Cruz; à la Compañia de Martinez una Tragedia en tres actos intitulada: Doña Maria Pacheco; he visto igualmente mucha concurrencia en dos dias, y he notado un silencio increible mientras há durado su representacion ${ }^{69}$.

Continúa después J. O. D. T. su escrito —en el que se adivina cierta propensión contra el pueblo llano- alabando las excelencias de la obra que, sobreponiéndose a febles imperfecciones, podría servir de ejemplo para combatir el desfavorable concepto que acerca de la industria de la escena sufrían los españoles entre los foráneos:

Los hombres de buen gusto y juicio á quienes hé oído hablar de ella, han hecho la justicia que merece su Autor, diciendo es una composicion en su clase, que aunque tenga algunos leves descuidos, ó defectos está arreglada á las leyes rigorosas del arte. Yo era de la misma opinion; pero para mas asegurarme la compré

crítico de las comedias anunciadas en los periódicos de Madrid desde 1661 hasta 1819, , Baltimore, The Johns Hopkins Press - Londres, Humphrey Milford, Oxford University Press - París, Société d'Édition Les Belles Lettres, 1935, pág. 75. La amistad entre Forner, autor del artículo, y García Malo nos es conocida gracias a una carta de Juan Clímaco de Salazar («nuestro comun y buen amigo Dn. Yg ${ }^{\circ}$ Malo») dirigida a D. Juan Pablo, y fechada en Roma el 21 de octubre de 1789, recogida en Cartas y papeles varios, según figura en la BNM, ms. 21.885, ff. 92v. y 93r.

68 Página 60, dentro de la anónima (firmada por «El Curioso») «Carta de un curioso que deseando le satisfagan á varias dudas que tiene, ofrece algunos premios». Este párrafo había sido ya citado también por Coe en su reseñado Catálogo bibliográfico y crítico..., pág. 169.

69 «Carta sobre el mal gusto del Vulgo». 
en casa de Castillo, la leí despacio, y considerando todas sus partes con imparcialidad, no he podido menos de admirarme de que llegue á tal extremo el mal gusto del populacho que prefiera à esta, otras piezas nuevas que se han representado por una y otra Compañia tan agenas del teatro, tan desarregladas, y tan faltas de raciocinio, que con razon pueden mofarse de nosotros los cultos extrangeros. La lastima no es esta, sino que como stultorum infinitus est numerus, atribuyen este mal gusto á toda la nacion, quando solo lo tiene el pueblo rustico que vá al teatro, mas para divertir la vista con las mutaciones de Escenas, la multitud de acciones y casos, ó inverosimiles ó impropios de la composicion Dramatica, (como son batallas, asaltos, muertes, desafios, y otros á este tenor que meten mucha bulla y estrepito) que para alimentar el entendimiento con aquellas acciones animadas solo del suave lenguaje dramatico y del raciocinio.

De estos antecedentes, más que de una presunta denostación de los comuneros y consiguiente rechazo de los espectadores por ello, es de lo que creemos se deriva una de las causas de la escasa presencia en cartelera. Y, a mayor abundamiento, detalla J. O. D. T., haciéndonos partícipes de ciertos rumores de entonces: «Parece, según he oído decir, que ha disgustado el que no haya mutaciones de escenas. He aquí el gusto de la turba multa». Remachando más adelante su razonar así:

Me remito al juicio de los inteligentes que podrán leerla para conocer mas la ignorancia del populacho. Si este fuera mas culto sabria distinguir lo bueno de lo malo, y conocería que esta pieza en su clase esta con bastante arreglo, bien conducida y manejada con viveza é inteligencia del Arte, pero se representarán malas comedias, llenas de monstruosidades é impropiedades, se alabarán injustamente por un sin numero de pedantones como sus autores; nuestro Teatro cada dia se corromperá, mas si es posible.

A compartir e ilustrar tan concreta preocupación ofrecerá el indicado «Discurso imparcial...», inserto en La Espigadera (págs. 20-21), el siguiente escolio:

Estas [Doña María Pacheco, entre ellas] y otras Piezas, que las mas guardan los que las escriben, han sido efectos de la diversion de sus Autores, fruto de sus ocios, partos de su aplicacion privada, trabajándolas para un honesto entretenimiento, sin pensar que se representasen, ni aun tal vez en que se leyesen, porque están bien persuadidos de que este exercicio no es hoy sino de copleros venales, y que las Compañías Cómicas, asidas á sus errores rancios, no buscan sino delirios con que llaman la plebe mas baja é idióta, como se ha verificado con la Comedia 
de Moratin el Viejo y la Niña, desechándola en otra ocasion al mismo tiempo que se representaba Marta la Romarantina.

Y en el caso que nos ocupa hay que añadir otro elemento reductor de la complacencia masiva: el del subgénero elegido. En la reseña que el Memorial literario brindó a Doña María Pacheco queda claramente de manifiesto el problema:

El vulgo no acostumbrado á juzgar segun estos principios no advierte estas delicadezas; y como al mismo tiempo esta es una accion ó Tragedia de las mas simples por una parte, y por otra de las menos agradables á quien está poco acostumbrado á ver Tragedias de todo género, no pudo parecer de grande interés ${ }^{70}$.

O como si se dijera, la falta de fervor popular pudo no provenir del contenido de la obra, sino de la específica formulación dramática utilizada, que en este caso, además, no se caracterizó en modo alguno por alcanzar las bendiciones del éxito o de la excelencia artística, puesto que, como asegura Ruiz Ramón, «la historia de la tragedia neoclásica es, desde el punto de vista de los valores literarios, la historia de un fracaso ${ }^{71}$.

Pero es que, aparte de eso, la consecución de una sustanciosa taquilla no dependía únicamente de la obra en sí, sino que otras variables, entre ellas las atmosféricas, ajenas por completo a aquélla, jugaban un decisivo papel. Y, si se duda de tal extremo, ahí está el testimonio de Leandro Moratín:

Supóngase que un escritor de conocido ingenio da al teatro por primera vez una comedia intitulada La dama duende. ¿Se representa en el mes de julio? Durará tres días y no producirá nueve mil reales de entrada. ¿Se representa en el de enero y llueve? Durará diez días y pasarán las utilidades de siete mil pesos. ¿No llueve? Al quinto día será necesario dejarla y la ganancia será mucho menor. ¿La desempeñan bien los actores? Se llenará el teatro de gente. ¿Se equivoca la elección de papeles, no se estudia, no se ensaya, no se adorna con decoro ni propiedad? El teatro quedará desierto.

70 Memorial literario, t. XVIII, 1789, págs. 121-122. Bastantes años después, Manuel Silvela coincidirá, igualmente, en la ingratitud de dicha especie teatral: «[...] por grande que sea el conjunto de bellezas literarias que encierre una obra trágica, por más que entusiasme a un auditorio erudito que en la lectura las saborea, raras veces alcanza a penetrar en el público, y no resiste a la prueba decisiva y suprema de la representación escénica» (Manuel Silvela, «Discurso», en Discursos leídos ante la Real Academia Española en la recepción pública de Don—, el día 25 de marzo de 1871, Madrid, Imprenta de M. Rivadeneyra, 1871, pág. 27).

${ }^{71}$ Francisco Ruzz Ramón, Historia del teatro español (desde sus orígenes hasta 1900), 3. a ed., Madrid, Cátedra, 1979, pág. 288. 
Y, acto seguido, remata: «De todo esto resulta que el premio destinado al autor de La dama duende no tendría relación ninguna con la bondad intrínseca de la obra, dependerá únicamente de circunstancias accesorias e inconexas, será desproporcionado, eventual e injusto» ${ }^{72}$.

Desconocemos la suerte que corrió la composición de Malo por lo que hace a los aspectos técnicos de la escenificación ${ }^{73}$, pero en cuanto a los climáticos fácilmente podrían haber sido más propicios, pues fue llevada a las tablas los días 7 y 8 de septiembre, en pleno verano madrileño, donde un cielo despejado y una temperatura en torno a los 25 grados centígrados (según se desprende de las «Afecciones Meteorológicas de ayer», recogidas en los consiguientes ejemplares del Diario de Madrid de los días 8 y 9 de septiembre de 1789) invitaban más al paseo y a la recreación al aire libre que a la reclusión en un recinto cerrado.

No será inútil constatar, tampoco, el hecho de que hubiese quien se maliciara algo más que lo apuntado para entender su temprano desvanecimiento del cartel. Ésa es la posición que sostiene J. O. D. T. en su reiterada «Carta sobre el mal gusto...»: «Pero si he de decir lo que siento no atribuyo todo lo que ha sucedido con la Pacheco al mal gusto del Pueblo; yo he notado alguna intriga sin duda de algunos pedantes; pues en los dos dias han sacado mas de 100 rs. y parece regular que hasta ver si decaia al tercero, se hubiesen seguido». Cuanto más que otros títulos con menores ingresos habían permanecido más días en escena $^{74}$.

72 Leandro Fernández de Moratín, La comedia nueva o el café, en La comedia nueva o el café y El sí de las niñas, ed., prólogo y notas de Federico Ruiz Morcuende, Madrid, Espasa-Calpe, Clásicos Castellanos, 1973, pág. 19, nota al pie del autor.

73 A este respecto, y al menos en lo que concierne al papel de la protagonista, parece que fue elegida la actriz más idónea para el mismo: María del Rosario Fernández, la Tirana; eso si atendemos a la muy cualificada opinión que sobre materia de teatros poseía Manuel Casal, y que al efecto manifiesta lo siguiente: «En las comedias de efectos expresivos amor, arrogancia ó heroismo, hallo sin igual á la Señora Maria del Rosario, como quien, á su bello decir, y ayroso estilo, une su representación magestuosa, y teatral dominio, mereciendo con justísimo titulo el papel de Dama» (Manuel Casal y Aguado, con su firma habitual de D. Lucas Alemán y Aguado, «Carta de Don Lucas Aleman», en el Correo de Madrid, de 9 de julio de 1788).

74 Para simple ejemplo, y tomando como indicador el promedio del taquillaje de los años inmediatamente anteriores al estreno de la Pacheco, se puede comprobar lo que decimos por medio del libro de Andioc Teatro y sociedad en el Madrid del siglo XVIII, págs. 38-39: «Cecilia, comedia sentimental de Comella, dura diez días en el Príncipe, aunque no obtiene, debido al calor de julio, más que una media discreta (3.625) [...] . La incógnita (Príncipe, nueve días, media 4.660) [...]. El señorito mimado, de Tomás de Iriarte, produjo efectivamente más de 32.000 reales en nueve representaciones en el Príncipe, debiendo tenerse en cuenta que el otro teatro permaneció cerrado cinco días». Coincide que las mencionadas son obras puestas en el recinto del Príncipe, pero la diferencia dineraria por venta de billetes con el de la Cruz no es significativa según recoge el mismo Andioc (pág. 37): «1786-1787: el precio de las localidades no ha sufrido variación (máximo del Cruz y del Príncipe: 5.770 y 5.720 por las comedias sencillas; 7.630 y 7.420 por las de teatro)». Sobre este particular puede consultarse René Andioc y Mireille Coulon, Cartelera teatral madrileña del siglo XVIII (1708-1808), 2. a ed., corregida y aumentada, Madrid, Fundación Universitaria Española, 2008, volumen I, «Introducción», págs. 16-18. 
Justamente hablando de Doña María Pacheco, de su condición de tragedia y del azar meteorológico, como factores de éxito o fracaso, y respondiendo, precisamente, al mentado J. O. D. T., encontramos el irónico y afinado tino de Manuel Casal y Aguado, que bajo el ya referido seudónimo de D. Lucas Alemán y Aguado, se expresa así:

No disputo el mérito de la tragedia de Doña Maria Pacheco, porque sobre no ser de mi parentela esa Señora yo entiendo de tales Dramas, lo que Vmd. Tal vez de hacer buñuelos. Para mi si ficit, atque bastat, que fuese tragedia, para no ir á verla al teatro, porque ni quiero pagar pesadumbres, ni meterme á llorar donde voy á divertirme [...].« Debiera decirnos con franqueza, si llovía, ó hacìa mal tiempo, porque entonces toda funcion es buena, por aquello de: acá me acojo, que no me $\operatorname{mojo}^{75}$.

\section{Hacia el pensamiento social y político del joven Ignacio García Malo}

Con el ánimo de intentar clarificar algunos puntos de la mentalidad de nuestro autor, nos valdremos ahora del ejercicio de ir realizando sucesivas calas retrospectivas en sus textos, partiendo de delante hacia atrás, con inicio en los años en los que resulta pública y notoria su ideología liberal, hasta concluir en la época en la que se fraguó Doña María Pacheco.

Es aquélla, primeramente aludida, la etapa en la que será capaz de publicar cosas del siguiente tenor:

En el tiempo del mayor despotismo de Carlos IV y de su privado, y en sus mismas secretarías del despacho, he tenido con muchos de sus oficiales las conversaciones mas liberales y patrióticas, respirando el mayor horror a la tiranía, que preveíamos iba a sumergir rápidamente a la nación en el abismo de males e infortunios que llora hoy. Debo a la verdad y a la justicia esta confesión ${ }^{76}$.

A este respecto, no deja de ser curioso que cuando García Malo dedica a Quintana La política natural, en 1811, lo haga relacionando, precisamente, el nombre del líder de los comuneros con el triunfo sobre la opresión: «[...] aque-

75 Manuel Casal y Aguado, «Respuesta á la carta del Diario 13 de Noviembre de 1789», Diario de Madrid, 2 de diciembre de 1789.

76 Ignacio García Malo, Reflexiones sobre los puntos más importantes en que deben ocuparse las Cortes. Con un apéndice [de Isidoro de Antillón] sobre los fueros de Aragón acerca de la libertad de imprenta, Palma de Mallorca, Imprenta de Domingo, 1810, págs. 32-33, nota. 
lla santa y justa libertad que V. invocaba cantando tan dignamente al inmortal PADILLA en tiempos en que ni aun se podia gemir sobre los males de la patria, sin esponerse á las delaciones, a los calabozos ó á la proscripcion» ${ }^{77}$. Y sería de extrañar justamente ese concreto recuerdo si Malo hubiera tenido conciencia de que, por su pluma, había alumbrado una pieza tan señaladamente contraria al asunto que encomiaba en su amigo Quintana.

Por supuesto que de inmediato habría que calificar de temeridad tratar de trasplantar el ideario del García Malo de 1811, de 1810, o de 1809, a la década de $1780^{78}$; sin embargo, debemos preguntarnos en qué momento apareció ese nuevo espíritu del cual surgieron «las conversaciones mas liberales y patrióticas», a que el propio García Malo se refería en las frases anteriormente transcritas.

Para este propósito habremos de servirnos de textos del propio Malo, obtenidos especialmente de su mentada colección narrativa Voz de la naturaleza, y remontarnos progresivamente, como hemos dicho, por el río del tiempo en que fueron escritos.

Así, comenzando por la última de sus novelas, El benéfico Eduardo, dada a la imprenta en 1803, podemos entresacar especulaciones del tipo siguiente:

La multitud de mendigos que vemos por todas partes, las infinitas y verdaderas necesidades, que oculta el pudór y la decencia, el desamparo y horfandad de muchas viudas é hijos de aquellos intrépidos y valientes militares, que en el campo del honor sacrificaron sus vidas, durante la guerra, en servicio del Rey y de la patria, y en defensa de nuestros hogares y propiedades, exîgen la compasión de todo hombre sensible («Advertencia», h.s.n.).

Tal vez por cautela enmascara aquí D. Ignacio, so capa de exhortar a los ciudadanos a practicar la caridad con los menesterosos, la crítica a un Estado que es el auténtico responsable de velar por los más necesitados; porque, si no, ¿a qué cuento se trae aquí al rey y a la patria?

77 Ignacio García MaLo, «Á don Manuel José Quintana», en La política natural ó Discurso sobre los verdaderos principios del gobierno. Le dá a luz Don—, Palma de Mallorca, Miguel Domingo, 1811, págs. VIIVIII; esta traducción resultó ser adaptación libre, bastante resumida y en algunos puntos creemos que autocensurada, de La politique naturelle, ou discours sur les vrais principes du gouvernement. Par un ancien Magistrat, Londres, 1774, s. i. García Malo se está refiriendo en estas páginas al poema de Quintana, fechado en mayo de 1797, con el título de Á Juan de Padilla, y que apareció publicado en Madrid en 1808, por la Imprenta Real, dentro de la obra Poesías patrióticas de D. Manuel Josef Quintana, págs. 8-17.

78 La síntesis política de Malo en los años ochenta, en cuanto a la relación entre el poder y los gobernados, quizá podría resumirse en la sentencia que, en el ámbito doméstico, propugna para la forma de corregir los maridos a sus mujeres: «que ni recele despotísmo ni conozca flaqueza» (El marido descuidado, pág. 82). 
La hipótesis de que García Malo va más lejos de lo que en realidad relata se manifiesta también en el recurso de pintar a Eduardo, el protagonista de dicha narración, como aficionado al estudio de la historia, para que, con esa excusa, pueda reflexionar sobre política, y hacerlo así

[...] contemplar la formacion de las sociedades, las resoluciones de los imperios, las costumbres de los pueblos, las vicisitudes continuas á que estan sujetos, la sobriedad de los unos, la magnificencia de los otros, las violencias, los trastornos, las desolaciones que han afligido y afligen la tierra, la perversidad de tantos monstruos como han producido solo para arruinarla, los pocos que con justa razon, pueden llamarse delicias del género humano (págs. 20-21).

El desengaño respecto de la clase gobernante nos parece claro. Tampoco pensamos que sea casualidad que, en sucesivas partes del libro, Eduardo vaya socorriendo a una multitud de desgraciados, pues se nos hace difícil imaginar que, a sus 43 años, García Malo escribiera una novela tan sencilla, y que las muchas calamidades que en ella pinta carezcan de un trasfondo de responsabilidad social o política; sino que creemos que posiblemente, de esa particular manera, pretendió inculcar la idea de que debería ser el Estado el encargado de socorrer tanto infortunio, muchas veces sobrevenido y a expensas de la voluntad de quien lo sufre: honrados trabajadores a quienes arruina una granizada, o a quienes el incendio de su casa deja en la indigencia; o bien que la muerte de los padres aboque a sus hijos a morirse de hambre. De ahí que, a la muerte de Eduardo, la gente exclame: «já quién recurriremos en nuestras desgracias! ¿Quién socorrerá á nuestros infelices hijos! Ya no tenemos quien nos liberte de una calamidad» (pág. 276, en cursiva en el original).

Tal vez habría que sincronizar el inicio de una importante evolución (o «revolución») en este tipo de planteamientos ideológicos con el advenimiento de Godoy al poder, así como con la posterior entrada en guerra con Francia, cuya causa principal fue la ejecución de Luis XVI. En este contexto no resultaría nada extraño que a García Malo se le abrieran los ojos y descubriera cómo un país entero y la vida de sus súbditos se ponían al servicio de los intereses familiares del rey de España ${ }^{79}$. Tampoco debemos olvidar que el puesto de Malo en la Secretaría del Vicariato General de los Ejércitos se erigía en una excelente atalaya desde la que se podía con más nitidez evaluar los horrores del conflicto armado.

79 Por escritos posteriores conocemos la antipatía que D. Ignacio llegó a tener por el monarca, así como por su esposa y, especialmente, por el privado. 
Prosiguiendo con nuestra regresión en el curso del tiempo, nos encontramos en El vicemariscal y Carlota (novela que pasó censura en marzo de 1792) con otra carga de profundidad para con los rectores de la patria:

Todos debemos desear hallarnos rodeados de amigos fieles, de hombres llenos de probidad [...]: pero iquanto mas deben desearlo, los que nos mandan y gobiernan, persuadidos de que sus aciertos ó yerros dependen las mas veces del bueno ó mal consejo de aquellos que tienen destinados para que les informen de los negocios, y les adviertan lo mejor! (pág. 183).

Unas páginas más adelante (221-222) ahonda en el problema: «Si los poderosos de la tierra considerasen bien los designios de Dios en haber puesto en sus manos la autoridad y el poder, no dispensarían su proteccion á los hombres viles, perfidos y aduladores».

¿Por qué impedir que el fantasma de la imaginación nos permita jugar con la idea de que García Malo se estaba refiriendo a Carlos IV y a Godoy? ¿Acaso éste no había sido nombrado precisamente vicemariscal (o brigadier) en enero de 1791, antes de ser ascendido a mariscal de campo en febrero, o a teniente general en julio de ese mismo año? Lo cierto es que en este relato de la Voz de la naturaleza no se escatima en representar la mezcla de asuntos oficiales con los meramente personales, el amiguismo, la componenda de quien ostenta un cargo público, la alianza, en fin, de hombres poderosos con fines inicuos ${ }^{80}$.

Esta lucha de García Malo contra la injusticia, en la medida de lo que sensatamente resultaba posible, es ya observable en obras anteriores. Así, a la altura de 1790, en Estanislao y Leonor clama el autor lo siguiente: «[...] la inocencia y la virtud agoviadas y oprimidas gimen y lloran báxo la miseria, el despotismo, la injusticia, la crueldad y el desprécio» (pág. 60).

E incluso antes de haberse publicado Doña María Pacheco, sabemos de esta preocupación de Malo por el mal funcionamiento del Estado y de su forma de administrar justicia. En 1787, con La desventurada Margarita (pág. 50), ya nos ponía en antecedentes: «A fuerza de dinero pervirtió la Justicia y equidad, buscó falsos testigos, tiró á denigrar á Margarita, y obró las mayores iniquidades ${ }^{81}$.

80 «Para que no sospecháse ella mutacion alguna en su falso amor, compuso [el vicemariscal] con el Ministro de Guerra, amigo suyo, sin revelarle la causa, que le enviáse fuera de Viena á evacuar una comision del Real servicio» (pág. 189). «Y el Ministro, que tenia una conciencia bien ancha, le aconsejó, que se ausentáse y dexáse á la inocente Carlota abandonada, y aun le dio una comision, para que de órden del Emperador pasáse á Londres á varios negocios» (pág. 217).

81 «Y aunque los Jueces conocieron la Justicia que asistia á Margarita, se dexaron arrastrar del interés» (pág. 51). «¿Podrá creerse semejante atentado? ¿Unos Jueces en quienes está depositada la fé pública y 
Desde luego que, de ninguna manera, pretendemos dar a entender que en esta década de los ochenta sostuviera Malo unas ideas tan avanzadas como para disentir del régimen, pero tampoco debemos perder de vista el hecho de que algo parecía estar «cociéndose» en su interior, una desazón nacida posiblemente de su afán por erradicar la opresión del poderoso hacia el humilde, pero que en modo alguno era el momento de explicitar; una concepción muy confusa y abstracta aún, que daba vueltas en un magma oscuro y todavía amorfo e intraducible, pero cuyo rastro emerge de vez en cuando al aire libre de su obra escrita, y que apunta a que, por dentro, quizá se estaba empezando a tornear el embrión ideológico, posteriormente consumado con su adscripción a las ideas liberales.

En esta misma línea, la hipótesis de que la Pacheco no es esencialmente producto de una dependencia empecinada y ciega hacia la estructura de poder permite descifrar, de modo diferente, comentarios que se tomaban como ratificación de esa presunta intención ideológica, como aquel de Iriarte que, en su censura del drama, asentaba esto: «[...] el Autor ha procurado inspirar horror á la rebeldía, y dexar castigada la traicion, sin lo qual habría inconveniente en exponer al Público unos exemplos de semejante naturaleza» (AHN, Consejos, legajo 5.553-75). Lo cual apunta a la imposibilidad de dar a la imprenta el libro con un final que fuera más favorable a los sublevados, y que por Serrano y Sanz — como antes recogimos — fue entendido como alabanza de D. Tomás a «la sumisión completa» de García Malo «a las autoridades, especialmente a la del Monarca».

Parejamente, las consideraciones, también más atrás consignadas, de Ramón del Toro podrían insinuar, entonces, que el dramaturgo había llegado hasta donde el buen sentido aconsejaba, viéndose, así y todo, unos años después, condenada la tragedia al ostracismo.

También Andioc observa más de un signo de simpatía hacia el bando rebelde, sobre todo en lo que atañe a la protagonista, haciéndole pensar que la figura de ésta pudo escapársele al escritor de las manos y que tal fenómeno constituyó la probable causa de aquella posterior interdicción de la pieza:

Et pourtant, force nous est de reconnaître que, malgré la nette orientation idéologique de la pièce, l'auteur ne nous présente pas une Doña María vraiment

\footnotetext{
la autoridad suprema, que su ministerio está establecido para que sirva de apoyo a los infelices, para castigar á los contraventores de las leyes, para administrar la justicia sin excepcion de personas, para defender al pupilo, para mirar por el honor de la doncella, atropellan todos estos respetos por un vil interés!» (págs. 51-52). Aunque, acto seguido (págs. 53-54), y seguramente para salvar la censura, se cura en salud (¿̨cómo hizo en Doña María Pacheco?) y exceptúa de la corrupción a las instancias judiciales superiores. Pero, en cualquier caso, la crítica quedaba ya manifestada.
} 
antipathique [...]. Enfin, il y a, si l'on peut ainsi dire, plus de conviction apparente dans les propos subversifs de Doña María que dans ceux de ses adversaires ou dans ceux que, comme une leçon bien apprise, elle tient après son repentir. García Malo n'aurait-il pas suffisamment dominé son sujet? [...]. Il nous paraît en tout cas difficile de trouver d'autres raisons à l'interdiction de la pièce par les auteurs du Teatro Nuevo Español ${ }^{82}$.

Así, en efecto, en el tomo IV del Teatro nuevo español, de 1801, y dentro de la «Continuación de la lista de las piezas recogidas», se puede leer su título (h. s. n.): «La muger de Padilla, Doña María Pacheco» .

Todo esto por no mencionar a Miguel Oliver, que, en su documentadísima Mallorca durante la Primera Revolución (1808 a 1814), afirma categórico: «De García Malo se representaba y aún se aplaudía con entusiasmo por sus arranques de "democratismo", Doña María de Pacheco».

\section{Conclusión}

Por todo lo anteriormente expuesto, juzgamos, en definitiva, y hora es ya de declararlo, que García Malo, hombre de los más templados y prudentes, profesaba — sobre todo en esa época en que escribe Doña María Pacheco- un extremado temor hacia las alteraciones o tumultos sociales, y que de esa inquietud y desvelo nace la obra que nos ocupa.

Consta plenamente acreditada su admiración ferviente hacia los principios liberales, cuyo desarrollo promoverá, junto con sus mejores amigos y camaradas (Manuel José Quintana, Isidoro de Antillón, Miguel Domingo, José Miguel Alea, etcétera), en los tiempos revueltos de la guerra contra Napoleón; esto es, cuando la lucha por alcanzar dichos ideales de ningún modo podía empeorar la estabilidad política y la pacífica convivencia. Lo que no sabemos es si tales ideas

82 René Andioc, Sur la querelle du téâtre au temps de Leandro Fernández de Moratín, págs. 321-322. En trabajos ulteriores, Andioc eliminará la referencia a esa «insubordinación» del personaje central (levantisco ya de por sí) para con la péndola del dramaturgo: «Cabe señalar sin embargo que, a pesar del enfoque decididamente proabsolutista del autor, Doña María resulta muchas veces conmovedora, por ser fiel a la memoria de un esposo amado, por mostrarse tan enérgica en una situación desesperada; varias actitudes de los Comuneros tienden a todas luces a suscitar cierta benevolencia por parte de los espectadores, y esto permite comprender en parte la prohibición fulminada más tarde contra la obra por los editores del Teatro Español» (René Andioc, «El teatro en el siglo XVIII», capítulo XIX de la Historia de la literatura española, planeada y coordinada por José María Díez Borque, vol. II: siglos XVII y XvIII, Madrid, Biblioteca Universitaria Guadiana, 1975, pág. 455). De igual manera se expresará en Teatro y sociedad en el Madrid del siglo XVIII, pág. 293, y en El teatro en el siglo XVIII, t. III de la Historia de la literatura española, planeada y coordinada por José María

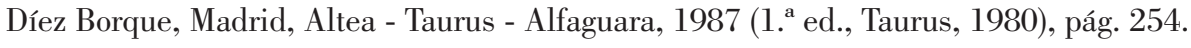


las sostenía ya con bastante anterioridad, bien que a escondidas, debiéndolas guardar por resultar locura manifestarlas públicamente e ir en contra del poder establecido; pero a buen seguro que, de todos modos, como causa añadida para callárselas, se sumaba en su conciencia el miedo a comprometer la paz civil.

Por tales razones, creemos que en Doña María Pacheco su reproche mayor será para las huestes comuneras, que revolvieron la paz. D. ${ }^{a}$ María y su ancila pagarán dicha osadía con la vida ${ }^{83}$. Pero no se escapan tampoco de la reprobación las banderas monárquicas que, por su comportamiento despótico y negligencia en los deberes para con el pueblo que gobiernan, han de padecer los horrores de una guerra (simbolizados en la pérdida de una hermana para Mondéjar, y en un hijo y una nuera en López), ni el mismo rey, que tiene que soportar la incertidumbre en sus dominios.

Todo ello a cambio del simple juramento final de acatamiento a la Corona por parte de una mujer derrotada y moribunda parece trueque desproporcionado y poco gustoso, especialmente en libro de ficción, en el que, si lo que se pretendiese fuera la glorificación del absolutismo, fácilmente podría haberse escogido otro distinto episodio.

Creemos, en cambio, que el mensaje de la obra está muy cerca de la siguiente síntesis - producto, si no concretamente de nuestro autor (cuestión que no somos capaces a determinar), sí de alguno de sus amigos y compañeros de ideología, allá por 1809—, siempre que, lógicamente, mutatis mutandi, sean salvadas las profundas diferencias que, de orden político-militar sobre todo, separaban a la sociedad de una y otra época:

Clamemos pues, á los monarcas. Moderad vuestro poder, si quereis conservarlo: y a los pueblos: templad el poder real, y sabed que quantos esfuerzos hagais por vuestra libertad, los haceis por la felicidad y la gloria de vuestro soberano. El mayor bien de los pueblos es ser obedientes á la ley: el mayor bien de los monarcas es la dichosa necesidad de ser justos ${ }^{84}$.

83 En realidad, por varios rasgos semejantes se echa de ver que es ésta hermana de la otra tragedia del joven García Malo, Guillermo de Hanau. Por ejemplo, en la privación de un bien perteneciente a cada uno de los protagonistas en beneficio de foráneos (gobierno en manos de extranjeros, en Doña María Pacheco; posesiones familiares regentadas por extraños, en el Guillermo); o en la alocada temeridad e imprudencia — fruto de la pasión y opuesta, por tanto, a la siempre anhelada razón — como desencadenante del desastre final. Por otro lado, ambos personajes principales que, a la postre, fallecen violentamente están a punto de ser salvados por sus respectivos hermanos, que les propician la huida de la Justicia.

84 «El poder arbitrario es funesto al mismo que lo exerce», anónimo, El Espectador sevillano, núm. 35 (de noviembre de 1809), pág. 143 (la cursiva de la cita está en el original). 